\title{
Fermented Cereal-based Products: Nutritional Aspects, Possible Impact on Gut Microbiota and Health Implications
}

\author{
Panagiota Tsafrakidou ${ }^{1} \mathbb{1}$, Alexandra-Maria Michaelidou ${ }^{2}$ and Costas G. Biliaderis ${ }^{2, *}$ \\ 1 Dairy Research Institute, General Directorate of Agricultural Research, Hellenic Agricultural Organization \\ DEMETER, Katsikas, 45221 Ioannina, Greece; panag.tsafrak@gmail.com \\ 2 Department of Food Science and Technology, School of Agriculture, Aristotle University of Thessaloniki, \\ 54124 Thessaloniki, Greece; amichail@agro.auth.gr \\ * Correspondence: biliader@agro.auth.gr; Tel.: +30-2310-991797
}

Received: 30 April 2020; Accepted: 26 May 2020; Published: 3 June 2020

\begin{abstract}
Fermentation, as a process to increase the security of food supply, represents an integral part of food culture development worldwide. Nowadays, in the evolving functional food era where new sophisticated technological tools are leading to significant transformations in the field of nutritional sciences and science-driven approaches for new product design, fermentation technology is brought to the forefront again since it provides a solid foundation for the development of safe food products with unique nutritional and functional attributes. Therefore, the objective of the present review is to summarize the most recent advances in the field of fermentation processes related to cereal-based products. More specifically, this paper addresses issues that are relevant to nutritional and health aspects, including their interrelation with intestinal (gut) microbiome diversity and function, although clinical trials and/or in vitro studies testing for cereal-based fermented products are still scarce.
\end{abstract}

Keywords: cereal-products; fermentation; nutritional aspects; health impact; probiotics; prebiotics

\section{Introduction}

The etymology of the term fermentation comes from the Latin verb "fevere", which means "to boil". Fermentation is one of the oldest known food processing methods and its history stretches back to the Neolithic period, as indicated by archaeological findings of clay tools for cheese making. Its unique ability to enhance the sensory properties of raw materials and preserve the developed product has been recognized throughout human history as miscellaneous fermented products are part of the culinary and cultural heritage of many countries globally [1,2]. This biotechnological method includes several subcategories based on primary metabolites produced: (a) alcoholic fermentation, conducted by yeasts, with ethanol and $\mathrm{CO}_{2}$ as the primary products; (b) acetic fermentation, conducted by bacteria of the genera Acetobacter with acetic acid as the primary product; (c) lactic fermentation, where lactic acid bacteria (LAB) are the fermenting microorganisms and lactic acid is the main metabolic product; and (d) ammonia or alkali fermentation of proteinaceous substrates by different Bacillus and Fungi species, with ammonia being released and giving the food a strong ammoniacal smell [3]. Their common aspect, from a biochemical point of view, is that microorganisms use their metabolic pathways to derive energy from organic compounds in the absence of exogenous oxidizing agents. Under this scope, any raw material containing organic compounds could be fermented by the microorganisms which possess the required enzymatic systems for degradation of the respective carbon sources. Recently, fermentation technology has been brought to the forefront again since it provides a solid background for the development of safe products with unique nutritional and functional attributes. 
Among the available fermented products, the cereal-based ones regained popularity in line with the ever-increasing health consciousness of consumers. Cereals are essential sources of carbohydrates, proteins, minerals, fibers, and vitamins. Table 1 presents the composition of indicative whole-grain flours of various cereals. Despite their drawbacks as raw materials (i.e., deficiency in certain amino acids, lower protein content, presence of antinutrient compounds) compared to products of animal origin or dairy foods, the fermented types of cereals are nutritionally superior to their native counterparts [4].

Table 1. Composition of whole-grain flours (adapted from [5]).

\begin{tabular}{ccccccc}
\hline $\begin{array}{c}\text { Type of } \\
\text { Whole-Grain } \\
\text { Flour }\end{array}$ & $\begin{array}{c}\text { Energy } \\
\text { (Kcal/100g) }\end{array}$ & $\begin{array}{c}\text { Protein } \\
\mathbf{( \% )}\end{array}$ & $\begin{array}{c}\text { Total Lipids } \\
\mathbf{( \% )}\end{array}$ & $\begin{array}{c}\text { Ash } \\
\mathbf{( \% )}\end{array}$ & $\begin{array}{c}\text { Carbohydrates } \\
\mathbf{( \% )}\end{array}$ & $\begin{array}{c}\text { Total Dietary } \\
\text { Fiber } \mathbf{( \% )}\end{array}$ \\
\hline Barley & 345 & 10.5 & 1.6 & 1.28 & 74.52 & 10.1 \\
Buckwheat & 335 & 12.62 & 3.1 & 2.54 & 70.59 & 10 \\
Corn & 361 & 6.93 & 3.86 & 1.45 & 76.85 & 7.3 \\
Millet & 382 & 10.75 & 4.25 & 1.21 & 75.12 & 3.5 \\
Oat $^{1}$ & 404 & 14.66 & 9.12 & 1.97 & 65.7 & 6.5 \\
Rice-brown & 363 & 7.23 & 2.78 & 1.54 & 76.48 & 4.6 \\
Rye-medium & 349 & 10.88 & 1.52 & 1.2 & 75.43 & 11.8 \\
Soft Wheat & 332 & 9.61 & 1.95 & 1.53 & 74.48 & 13.1 \\
Sorghum & 359 & 8.43 & 3.34 & 1.32 & 76.64 & 6.6 \\
Teff & 366 & 12.2 & 3.66 & N.A. ${ }^{2}$ & 70.73 & 12.2 \\
\hline
\end{tabular}

${ }^{1}$ Partially debranned, ${ }^{2}$ N.A.: Not Available.

As plant-based matrices, fermented cereal products are suitable for people with lactose intolerance, milk allergies, or people who follow a low lipid or vegan dietary pattern. They are also considered as novel probiotic delivery vehicles and potential functional foods [6]. Fermented foods' consumption has been linked with beneficial health attributes [7] and as a whole, they represent $20-40 \%$ of the international food supply [8]. Fermentation enhances the palatability of the grains through textural and flavor changes, thus reducing the need for flavorings or other additives. Cereal grains in their raw form are characterized by low levels of organoleptically-active compounds, which corresponds to a rather flat flavor, which is often unpleasant to consumers. However, the enzymatic activity of LAB on the cereals' components generates volatile (carboxylic acids, alcohols, aldehydes, ketones, and esters) and/or non-volatile compounds (sugars and carboxylic acids) that contribute to the sweet and sour taste and specific aroma of each product, especially in cereal-based beverages [9]. In order to promote the traditional fermented cereal products of each region in new or global markets, cross-border consumers' acceptance needs to be met. Studies regarding consumers' acceptance have been conducted for some products [10-12]. For example, Akissoé et al. [13] conducted research regarding consumers' preference on five different types of Akpan (a cereal-based beverage from Benin). Consumers were male and female individuals, both African and European, who scored the Akpan samples using a nine-point hedonic box scale regarding the taste, appearance, and overall acceptance. Recorded differences between the Africans and Europeans highlight the importance of these types of consumer studies to re-engineer traditional products and succeed in new markets penetration.

Figure 1 depicts the growing interest in this thematic area during the last decade. This could be attributed to the significant advancements in various branches of science, like food science, medicine, biology-biotechnology, genetics, etc. and to the technological innovations linked with the development of analytical methods and tools to enlighten compositional and functional elements previously identified as "black boxes". 


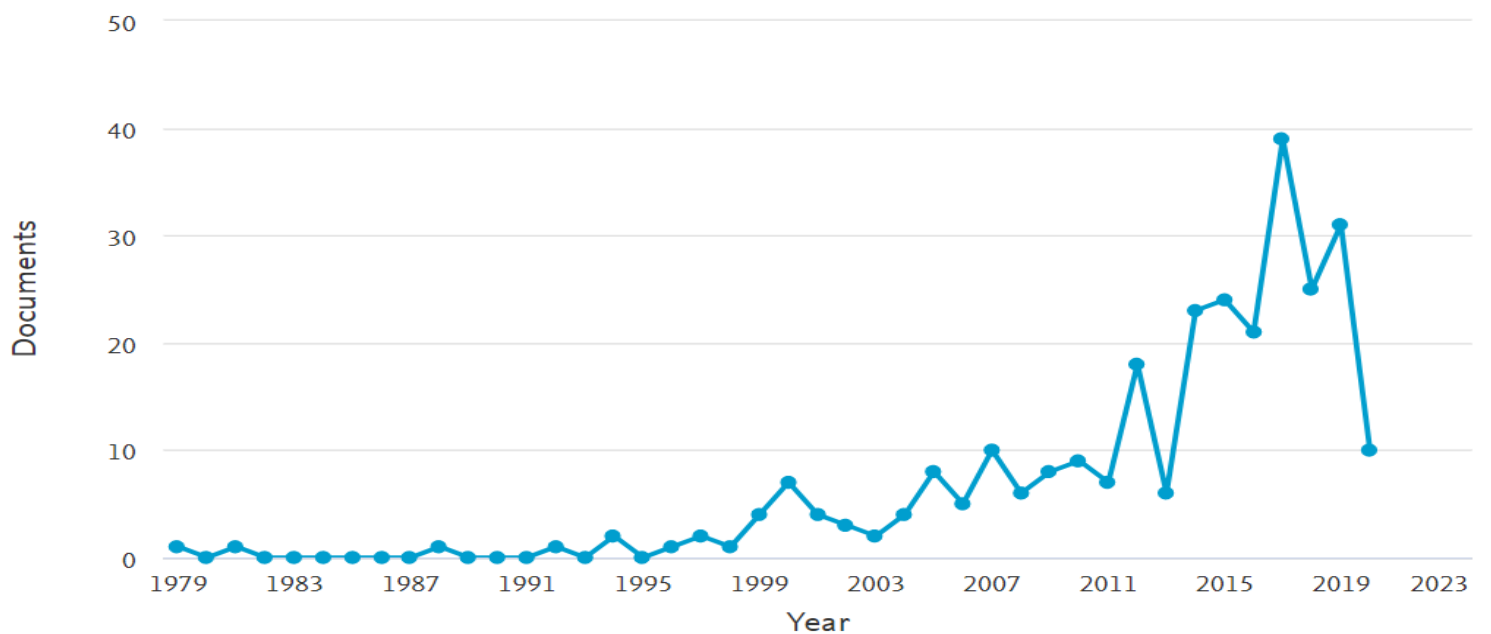

Figure 1. Number of articles published on fermented cereal-based products over the period 1979-2020, according to the Scopus database (last accessed 23/04/2020, document search: "fermented AND cereal AND based AND products").

This paper aspires to present the latest findings of research that is being conducted regarding the nutritional aspects and functional properties of fermented cereal-based products, emphasizing the traditionally prepared foods and excluding alcoholic beverages which follow a discretely differentiated production technology.

\section{Nutritional Aspects of Cereal-Based Fermented Foods}

\subsection{Impact on Food Safety and Shelf-Life Extension}

Fermenting microorganisms employed to generate new products with improved sensorial and nutritional qualities often produces various metabolites that inhibit the growth of spoilage and/or pathogenic bacteria. These metabolites include organic acids such as lactic acid, propionic acid, acetic acid, etc. that decrease the initial $\mathrm{pH}$ value, creating an acidic environment in the food matrix and therefore extending the shelf-life of the fermented product [7]. Furthermore, ethanol and hydrogen peroxide, which are strong inhibitory factors for microbial growth, as well as other secondary metabolites that can act as antimicrobial compounds, are produced by some LAB and yeast species. These metabolites can be effective in controlling fungal growth and mycotoxins production in grain matrices; the latter is of great importance for cereal derived products, raising public health concern since exposure to mycotoxins may cause adverse health effects to humans [14].

Lactobacillus and Pediococcus strains, possessing antimicrobial activities, were tested regarding their efficiency to reduce mycotoxin production from Fusarium as well as to restrain the growth of other mycotoxigenic fungi during malting of wheat grains (used for beverages and bakery products). LAB reduced the fusarium toxins (deoxynivalenol-vomitoxin-, T-2, HT-2, and zearalenone) by up to 75\%, depending on the strain. Antifungal activity was also observed from LAB metabolites (especially from acetic acid and secondarily from lactic acid) [15]. Naturally fermented sorghum, used to produce whole grain Ting (an African traditional food), was compared to similar products fermented with the addition of Lactobacillus fermentum strains as starter cultures. The content of mycotoxins (found in the whole grain of sorghum raw material) was decreased in all fermented samples. More specifically, L. fermentum FUA 3321 reduced the studied mycotoxins by up to 98\% [16]. Moreover, traditional fermentation processes reduced the mycotoxin content of kunu-zaki and pito (two popular traditional cereal-based African beverages) by $59 \%$ and $99 \%$, respectively [17]. The antifungal properties of various Lactobacillus strains have been tested in-situ to evaluate their effectiveness to improve the quality and safety of fermented cereal products. It is believed that the antifungal effect of LAB is the result of synergistic interactions among numerous metabolites, including fatty acids, peptides, and organic acids [18]. 
Antimicrobial peptides, bacteriocins, are produced by LAB and are partially related to the extended shelf-life of fermented products [19]. M'hir et al. [20] reviewed the enterococci strains that were isolated from fermented cereal products and their potential usage as starter cultures according to their technological, functional, and safety characteristics. The antimicrobial activity of 63 LAB isolates from a spontaneously fermented beverage (ogi) was explored. Pediococcus sp. strain OF101 showed the highest antibacterial activity against several tested food pathogens (Bacillus cereus, Staphylococcus aureus, Listeria monocytogenes, Enterococcus faecium, and Escherichia coli) [21]. Likewise, Chinese fermented foods, including sweet fermented rice, homemade sourdough, and koji, were the samples from which $132 \mathrm{LAB}$ isolates were obtained. All isolates exhibited antimicrobial activity and reduced the five indicator pathogens (E. coli ATCC 25922, Salmonella enteritidis ATCC13076, Salmonella typhimurium ATCC14028, L. monocytogenes EGD-e, and S. aureus ATCC29213) by 2-4 log CFU/mL [22]. Consumption of traditional fermented cereal products in Africa resulted in reduced diarrhea outbreaks in children by $40 \%$ and improvement in well-being [7]. These findings indicate that isolated microbial strains from indigenous products may be used as starter cultures for standardized production of the respective cereal-based fermented product after their evaluation for technological and probiotic properties [18] or as sources to isolate metabolites and use them as pure antimicrobial agents [6].

\subsection{Enhancement in Nutritive Value and Compositional Changes of Fermented Cereal Products}

In the following subsections, an overview of the nutritional value and compositional changes due to the fermentation of cereals is presented.

\subsubsection{Protein and Carbohydrate Digestibility}

Protein digestibility depends on the protein structure and the presence of antinutrient factors (protease inhibitors, phytases) that bind with them as well as other parameters such as $\mathrm{pH}$, temperature, and ionic strength, all of which are directly related to proteolytic activities. Fermentation may affect these factors and parameters and thereby contribute to a more effective digestibility of plant proteins [23]. Proteins need to be broken down to amino acids or even small peptides to enter the human bloodstream after their absorption by the enterocytes of the small intestine, otherwise they reach the large intestine where they are fermented by the gut microorganisms, giving rise to the formation of amines and short-chain fatty acids. These fermentation products elicit various biological reactions via different receptors and mechanisms, including signal transduction involving biogenic amines as neurotransmitters and modulation of inflammatory responses [24].

Upon fermentation, microbial proteases are released and degrade to a certain extent the proteins included in a composite food matrix like cereal grains. Furthermore, the improvement of protein digestibility is accomplished through the reduction of antinutrient factors [25]. The role of phytate and polyphenols and how fermentation affects them is further analyzed in Section 2.5 (Reduction of antinutrients and allergens). Subsequently, the inactivation of digestive enzymes' inhibitors (trypsin and chymotrypsin inhibitors) in fermented cereal products is being discussed.

The effect of fermentation on trypsin and chymotrypsin inhibitors was evaluated in bread samples made from various cereals (wheat, whole wheat, rye mix, and mixed flours). In the case of rye mix bread, the final trypsin inhibitors were almost half compared to the concentrations measured in the respective raw flour. An interesting observation was that whole wheat flour dough and bread did not exhibit any trypsin inhibitory activity, which was attributed to the bran content and the formation of complexes between the bran's polysaccharides and the proteases inhibitors [26]. Montemurro et al. [27], studied the effect of germination and fermentation on the nutritional value and functional and technological properties of sourdough. Overall, bread made of sprouted and fermented flours showed high protein digestibility and low starch availability. Similarly, the in vitro starch and protein digestibility of fermented sorghum flour by LAB was improved. The LAB strains used have previously been isolated from fermented maize and sorghum and were chosen based on specific characteristics, e.g., $\mathrm{pH}$ tolerance, acidifying activity, and salt tolerance [28]. Natural fermentation 
enhanced protein and starch digestibility of complementary products (foods other than breast milk or infant formula - in the form of liquids, semisolids, and solids—introduced to an infant to provide nutrients) prepared from different ratios of flour blends from sorghum, millet, pumpkin, and amaranth seeds [29].

Carbohydrates digestibility is of great importance as well since it is related to many human health issues. Starch digestion is directly linked to the glycemic index (GI) of foods and concerns diabetic and health-conscious consumers who prefer products that do not rapidly raise glucose levels in blood and therefore avoid risks of insulin resistance and type 2 diabetes. Sourdough fermentation alters the cereal matrix through the production of lactic acid, which aids interactions between starch and gluten. These interactions result in reduced starch availability and a lower GI for the product [25]. Autochthonous LAB were used to ferment quinoa flour sourdough. The latter replaced the semolina needed to produce pasta by $20 \%$. The predicted GI was lower with the fermented product, compared to the control pasta (made of wheat flour) [30]. It is worth mentioning that amylolytic LAB are scarce and limited species possess the gene amyA, which is responsible for the production of the extracellular enzyme $\alpha$-amylase; actually, the formation of lactic acid from starch depends on the expression of this gene. The most efficient lactobacilli (e.g., Lactobacillus amylovorus) regarding starch fermentation ability belong to the genera Lactobacillus, Lactococcus, and Streptococcus [31].

Patients suffering from irritable bowel syndrome (IBS) are instructed to avoid cereals and follow a diet with low content in easily fermentative sugars. These sugars include "Fermentable Oligo-, Di- and Mono-saccharides and Polyols", FODMAP in short. Fructans, galactans, lactose, fructose, sorbitol, and mannitol are not absorbed in the small intestine and are rapidly fermented by gut bacteria when they reach the large intestine, thus inducing abdominal symptoms (diarrhea or constipation, swollen belly, meteorism, abdominal pain, etc.) [25,32]. During fermentation, LAB, yeasts, and fungi totally or partially degrade FODMAPs. Regardless of the extent of degradation, the decrease of FODMAPs is beneficial for people with IBS symptoms, since their adverse effects depend on FODMAPs' intake dose [33]. There are various published data regarding the content of cereal products in such sugars [34-37], but only a few reported studies are concerning the production of cereal-based products with low-FODMAP content. Struyf et al. [38] reduced the FODMAP content in whole wheat bread by more than $90 \%$ by the addition of Kluyveromyces marxianus and baker's yeast (Saccharomyces cerevisiae) in the dough. Control bread made only with K. marxianus did not reach a desirable loaf volume due to insufficient $\mathrm{CO}_{2}$ production. Therefore, the co-culture of the two yeasts is essential for products with acceptable sensory characteristics (volume, texture, flavor) and low FODMAPs content. Menezes et al. [39] emphasized the need for combining microbial enzymatic activities from $\mathrm{LAB}$ and yeasts to produce added value bread that suits special dietary needs and do not lack in quality attributes. To this end, single sourdough yeast isolates were tested on their FODMAP reduction activity and $\mathrm{CO}_{2}$ production in a model system simulating wheat bread fermentation. S. cerevisiae and Torulaspora delbrueckii, obtained from Austrian traditional sourdough, were the most effective yeast species regarding the degree of degradation of the fructans and having the highest $\mathrm{CO}_{2}$ production capacity [40]. The research findings from these studies point to the potential of employing mixed cultures (LAB and yeasts) to produce palatable bakery products with improved nutritional and leavening characteristics.

\subsubsection{Dietary Fiber Modification}

According to the American Association of Cereal Chemists (AACC), dietary fibers (DFs) are plant carbohydrates that are resistant to hydrolysis by human enzymes but can be fermented by microorganisms in the large intestine. They are classified in soluble and insoluble DFs and their ratio in food products plays a significant role in both health implications and physical-technological properties [41].

Cereals contain various DFs, which chemically and compositionally differ depending on the type of cereal and grain tissue in which they are found. The main components of DFs of cereals are 
non-starch polysaccharides, i.e., arabinoxylans, $\beta$-glucans, cellulose, resistant starch, fructans, and lignin, which are a phenolic polymer and often exist in composite structures with other small molecular weight bioactives, e.g., simple phenolics, minerals [42]. During fermentation of cereals, the $\mathrm{pH}$ is decreased due to the production of organic acids (mainly lactic and acetic) and this may result in the activation of various enzymes, either endogenous of the grains or bacterial. The enzymatic activity is responsible for biopolymer degradation, leading to grain softening (cell wall degradation) and improvement of the sensory and physiological characteristics of the fermented product [43].

Recently, the effects of fermentation by Lactobacillus plantarum dy- 1 on barley $\beta$-glucan's physiological and structural properties were reported [38]. Fermentation altered the state of $\beta$-glucan from a compact form (rod-shaped) in the raw barley to a smooth sheet-like structure in the fermented barley. This morphological reshaping may contribute to enhanced water adsorption or molecular binding ability. An in-depth structural analysis (NMR, FTIR, methylation analysis, monosaccharide composition) revealed that fermentation decreased the molecular weight of $\beta$-glucans (from $1.13 \times 10^{5} \mathrm{D}$ to $\left.6.35 \times 10^{4} \mathrm{D}\right)$ and modified the $\beta-(1 \rightarrow 3)$ residues to the $\beta-(1 \rightarrow 4)$ residues ratio, from 1:1.98-1:2.50 in the raw barley to 1:1.8-1:2.24 in the fermented samples. These structural modifications had an impact on the physiological activities of these polysaccharides as assessed by in vitro protocols. The hypoglycemic activity was evaluated by measuring the inhibitory effect on $\alpha$-amylase and $\alpha$-glycosidase, inhibition of lipase was measured to determine the potential reduction of fat absorption during digestion by barley consumption, and finally, the capacity of cholesterol (re)absorption was determined for both control and fermented samples. Although all physiological activities of barley $\beta$-glucans were enhanced upon fermentation, such findings remain to be proven as actual physiological responses by in vivo testing [44]. Wheat bran fermentation by Lactobacillus rhamnosus 1473 tripled its water-extractable arabinoxylans (WEAX) due to the activity of endoxylanases on high molecular weight arabinoxylans [45]. The content of WEAX in flour is of great importance for the rheological characteristics of the dough and the quality of the final product [46]. Moreover, it is well known that WEAX in bakery and other cereal products increase the viscosity of the intestinal contents (digesta) and this, in turn, enhances the hypocholesterolemic and hypoglycemic potential of these food items. Zhao et al. [47] studied the impact of different fermentation procedures of wheat bran. The investigated matrix was fermented with baker's yeast, LAB starters (Lactobacillus bulgaricus and Streptococcus thermophilus), a combination of the previous cultures, and without the addition of microorganisms (i.e., spontaneous fermentation). The effect of heat treatment (autoclave sterilization) was also evaluated. The content of WEAX significantly increased in all fermented samples by three to four times, compared to the untreated wheat bran. Soluble dietary fiber (SDF) content was also increased in fermented wheat brans, which is in accordance with data regarding SDF in sourdough production from rye [48]. A combination of fermentation and enzymatic pretreatment can thus valorize cereal brans to produce modified high fiber flours, with technological properties similar to those of refined flour streams. Overall, certain bakery products with improved nutritional value can be produced, ameliorating the undesired effects of untreated bran addition (hardness, low loaf volume, negative sensory features) [49].

\subsubsection{Vitamins}

Vitamins play a crucial role in proper metabolic functions and therefore, their daily intake is essential since they cannot be synthesized at adequate amounts (or at all) in the human body. These essential micronutrients are divided into two sub-categories according to their solubility: a) the water-soluble vitamin $C$ and the group of $B$ vitamins (thiamin-B1, riboflavin-B2, niacin-B3, pantothenic acid-B5, pyridoxine-B6, biotin, folic acid, cobalamin-B12), and b) the fat-soluble vitamins A, D, E, and $\mathrm{K}$ [50]. Although cereals contain specific vitamins, fermentation with LAB or yeast strains can increase their vitamin content $[7,8]$. The ability of LAB to produce vitamins is strain-specific and these microorganisms could be used as starter or added cultures to fortify naturally fermented products for targeted nutritional and quality improvement. Such a fortification is of great importance for specific population groups that follow special types of dietary regimes, either by choice (e.g., vegans) or due 
to cultural habits, religious beliefs, and lack of other available food sources (developing countries). It is worth mentioning that in some African countries, porridges made of cereals can complement breastfeeding [51,52].

Biofortification in vitamins of fermented cereal products has been attempted by a few researchers [53]. For example, the incorporation of Lactococcus lactis N8 and Saccharomyces boulardii SAA655 in idli batter (an Indian steamed cake made from rice and legumes) increased the riboflavin and folate content by $40-90 \%$ [54]. Sourdough bread and pasta (with a pre-fermentation step) that were fermented by two L. plantarum strains showed a threefold and twofold increment, respectively, in their vitamin B2 content. The used strains were isolated from durum wheat flour and have been characterized as riboflavin-overproducing microorganisms according to in vitro tests with synthetic media [55]. More recently, Bationo et al. [52] reported that processing steps like debranning, soaking, and wet-milling may cause a decrease in cereals' folate content by up to $60 \%$, while on the contrary, fermentation increased folate's concentration by up to $27 \%$. Various fermented cereal-based foods were studied (fritters, dumplings, porridges, and gelatinized doughs, made from sorghum, corn, or pearl millet) and their estimated folate bioaccessibility ranged from $23 \%$ to $81 \%$ using an in vitro digestion model. According to Chaves-Lopez et al. [31], spontaneous maize fermentation may enhance the concentrations of nutritional compounds (thiamine, folate, riboflavin, total carotenoids, vitamin C, and vitamin E), but further preparation steps of the traditional foods result in significant decrements of each important nutrient.

Raw cereals and cereal-based fermented products are a valuable source for the isolation of vitamin producing strains. Carrizo et al. [56] isolated, identified, and evaluated the B-group vitamin production of LAB from quinoa grains and quinoa sourdough. The microbial isolates presented phytase activity, riboflavin, and folate production. Consequently, these strains could be used as ideal starter cultures to produce fermented quinoa (or other cereal) foods with enhanced nutritional value. Propionibacterium freudenreichii produced active B12 vitamin to an adequate level when malted barley flour, barley flour, and wheat aleurone were used as fermentation substrates [57]. In situ production of B12 by $P$. freudenreichii was also achieved with the fermentation of wheat bran [58]; co-fermentation using both $P$. freudenreichii and Lactobacillus brevis was investigated in this study to assess the microbial composition at the end of the process. Although co-fermentation resulted in lower concentrations of vitamins (also dependent on $\mathrm{pH}$ control throughout the fermentation process), the presence of $L$. brevis was essential to inhibit the growth of Enterobacteriaceae and B. cereus and thus, to ensure the microbial safety of the bran dough [58]. Greppi et al. [59] studied 151 isolates from four species (L. fermentum, L. plantarum, Pediococcus acidilactici, and Pediococcus pentosaceus) obtained from a millet-based fermented food. Their results indicated that besides the strain's characteristics, folate production depends significantly on the duration of fermentation and the composition of the medium.

Furthermore, there are limited reports on the effect of bacterial and yeast/fungal fermentation of cereals on vitamin E concentration. Stale rice was fermented with Cordyceps sinensis and vitamin E increased $100 \%$, compared to the control unfermented sample [60]. Lisosan $G^{\circledR}$, a nutritional supplement made from wheat germ and fermented bran with a mixed culture of LAB and yeast strains, in feeding trials using rabbits resulted in increased vitamin A and E levels in blood and showed reductions of triglycerides, LDL cholesterol, and blood reactive oxygen metabolites (antioxidant activity) [61].

\subsubsection{Phenolic Components}

Phenolic components, which are secondary plant metabolites, are also found in notable amounts in cereals [60]. The metabolic pathways (shikimate, phenylpropanoid) for their biosynthesis involve many biomolecules like acetyl CoA, malonyl CoA, pyruvate, acetate, and some amino acids (phenylalanine and tyrosine) [16]. Their beneficial properties in human health (anti-diabetic, anti-cancer, anti-inflammatory, anti-microbial, anti-oxidant, as well as neuro-, cardio-, and hepato-protective function) are attributed to their ideal chemical structure, which promotes electron transfer or hydrogen 
donation from the hydroxyl groups of their aromatic ring and thereby exhibit free radical scavenging activities and metal-chelating potential $[60,62,63]$. Phenolic components need to be in a soluble form to enter the human blood circulation system and bring about their antioxidant properties. Phenolics in cereals can be found as free and soluble, conjugated and soluble (bound with sugars and sterols), and non-soluble, which are usually linked to polymers like arabinoxylans and lignin [63,64]. Increases of cereals' phenolic content can be achieved by size reduction of the particles, germination, addition of hydrolytic enzymes, and fermentation [63]. Fermentation is reported to also enhance the antioxidant activity of the phenolic fraction [65]. The conditions during fermentation (temperature, final $\mathrm{pH}$ value, duration), microorganisms involved, as well as the type of cereal and the grain tissue employed play an important role in the outcome concerning the release of the bound phenolics $[62,66,67]$.

Fermentation of millet with a mixture of Lactobacilli, mainly Lactobacillus sanfranciscensis, Lactobacillus pentosus, and yeast strains in a ratio of approximately 100:1 increased the total phenolic content by 30\%, thus improving the nutritional and functional value of this underutilized cereal [68]. Wheat bran and oat bran were used as solid-state fermentation substrates by yeast (S. cerevisiae). Total phenolic content (TPC), composition of extracted phenolics, and antioxidant activity (in vitro) were evaluated. The best results were obtained at three days of fermentation, with a high correlation between antioxidant activities and the highest TPCs [62]. Quinoa sourdough, fermented with autochthonous lactic acid bacteria (previously isolated from the same pseudo-cereal), was used to nutritionally enrich white wheat bread. Total phenols and antioxidant activity were significantly higher in the samples containing the fermented quinoa preparation [69]. The effect of fermentation on the TPC and antioxidant activity of maize [70], oat [71], and rye [72] has been highlighted in numerous studies [25,73]. Oats are a rich source of polyphenols and avenanthramides in particular. The latter phenolic alkaloids have been reported to exhibit anti-inflammatory, antioxidant, antiatherogenic activities, and other health benefits [74]. After 4 days of fermentation, solid-state yeast fermentation of oat bran increased the apparent avenanthramide content by $48.5 \%$ and the ferulic acid content by $21.2 \%$, which is most likely due to degradation of the compact grain cell wall matrices. The same process also increased the total phenolic content of wheat bran, where the highest percentages were obtained on day 3 [75]. Adebo and Medina-Meza [76] have published a comprehensive review of the impacts of fermentation on antioxidant activity and specifically the fate of phenolic compounds of whole cereal grains. They conclude that fermentation could positively alter not only the nutritional value of whole-grain foods, but also their sensory characteristics to allure consumers. A thorough investigation of the bioavailability of phenolic compounds concerning different fermentation media and conditions used, as well as the type of culture employed (microbial strains), is still needed to support the health benefits originating from the phenolics fraction in fermented products made from cereals.

\subsection{Cereal-Based Fermented Foods as Probiotic Carriers}

Nowadays, the market value of functional foods and beverages is growing with an average rate of $8.6 \%$ globally [77], leading the related industries to a quest of alternative and novel products to meet the consumers' needs, stay competitive, and ensure their future survival in the globalized functional foods arena. Probiotics have been associated with dairy products for many years, but milk presents many drawbacks as a raw material according to the new trends of the food sector. From an environmental point of view, production of dairy products is generally considered among the possesses that have the greatest burdens based on life cycle assessment analysis [78]. In addition, lactose intolerance and allergies related to milk proteins concern the vast majority of the world's population and is an issue that producers should take seriously when developing functional dairy products. Other shortcomings of dairy product matrices include the high cholesterol and fat content, cultural and strict religious beliefs of specific populations that prohibit the consumption of such foods, new diet trends, like veganism, in developed countries, as well as limited access or storage capability of dairy products in developing countries $[77,79,80]$. Other products that may also serve as probiotic carriers are meat, fish, chocolate, 
vegetables, fruit, and cereals. For the purposes of the present review, cereal-based products will be further discussed in this context.

As previously stated, cereals, containing a plethora of nutrients and bioactive compounds, are perceived positively by consumers as a healthy food choice and are cultivated and consumed all over the world. This is indicated by the overabundance of traditional fermented cereal-based foods as summarized in Table 2. However, the production of such food items, including drinks, is often characterized by uncontrolled conditions, which enhances the growth of mixed microbial populations. The predominant microorganisms in these products belong to $\mathrm{LAB}$, but limited information concerning their probiotic features was available until now. Unstandardized production conditions and variances of the type and quality of raw materials complicates the procedure of identifying and studying the potential probiotic strains associated with specific end-products [80]. In vitro tests for probiotic characteristics were performed for amylolytic LAB strains, isolated from Chinese fermented cereal foods (sweet fermented rice, homemade sourdough, and koji). Three of the isolates were identified as L. plantarum strains and demonstrated higher or equal bile salt and acid tolerance, resistance to antibiotics, antibacterial activity, and adhesion-aggregation activities with the control commercial strain, L. rhamnosus ATCC 53103 [22]. Trahana (tarhana), a staple food made of wheat flour and yogurt, mainly produced and consumed in Greece, Cyprus, and Turkey, is considered to be one of the first probiotic foods [8]. Boza is another fermented beverage made of various cereals (millet, wheat, maize, rice, barley, oat, rye), which is consumed in the Balkan Peninsula, Turkey, N. Africa, and S. Russia. A varied microbial community responsible for boza's fermentation is the consequence of the wide range of raw materials used as fermentation substrates as well as the different geographic regions (varying technologies) in which it is produced. Different bacterial species' strains with probiotic properties have been isolated from boza [8]. Recently, a traditionally fermented sourdough from Arasbaran in Iran was used as a source for bacteria and yeasts that present probiotic properties and could be used as starter culture medium for the production of probiotic whole wheat bread. The isolates also improved the antioxidant capacity via fermentation, produced phenolic compounds, and degraded phytate, which is an important nutritional issue for whole-grain fermented products [81]. 
Table 2. The most common traditional cereal-based fermented foods and beverages worldwide.

\begin{tabular}{|c|c|c|c|c|c|}
\hline Name & Cereal Used & Fermentation Microorganism (s) & Country/Region of Origin & $\begin{array}{l}\text { Type of } \\
\text { Product }\end{array}$ & Reference \\
\hline Boza & $\begin{array}{c}\text { Millet, Wheat, Maize, Rice, Barley, } \\
\text { Oat, Rye }\end{array}$ & LAB & $\begin{array}{l}\text { Bulgaria, Albania, Turkey, } \\
\text { Republic of Northern Macedonia, } \\
\text { Romania, S. Russia, N. Africa }\end{array}$ & Beverage & [8] \\
\hline Bushera & Sorghum, Millet & LAB & Uganda & Beverage & {$[8,77]$} \\
\hline Cheka & Sorghum, Maize & Unknown & SW. Ethiopia & Beverage & [82] \\
\hline Chicha & Maize & LAB, Acetobacter & Peru & Beverage & [83] \\
\hline Dhokla & Rice & $\begin{array}{l}\text { Leuconostoc mesenteroides, L. fermentum, } \\
\text { P. pentosaceus, Pichia silvicola S. cerevisiae }\end{array}$ & India & $\begin{array}{l}\text { Steamed } \\
\text { Cake }\end{array}$ & {$[8]$} \\
\hline Dosa & Rice & $\begin{array}{l}\text { L. mesenteroides, Streptococcus faecalis, L. } \\
\text { fermentum, Bacillus amyloliquefaciens }\end{array}$ & S. India & Pancake-Like & [8] \\
\hline Idli & Rice & $\begin{array}{l}\text { L. mesenteroides, Lactobacillus delbrueckii, } \text { L. } \\
\text { fermentum, L. lactis, S. faecalis, Pediococcus } \\
\text { cerevisiae, L. plantarum } \\
\text { Subsp. plantarum, L. pentosus, L. plantarum } \\
\text { spp. argentoratensis }\end{array}$ & India, Sri Lanka & $\begin{array}{l}\text { Steamed } \\
\text { Cake }\end{array}$ & {$[8]$} \\
\hline Injera & $\begin{array}{l}\text { White or Red Sorghum, Tef, Wheat, } \\
\text { Barley, Finger Millet Or Maize }\end{array}$ & $\begin{array}{c}\text { Pullaria sp., Aspergillus sp., Penicillium sp., } \\
\text { Rhodotorula sp., Hormodendrumsp., } \\
\text { Candida sp., L. bulgaricus }\end{array}$ & Ethiopia, Africa & Pancake-Like & {$[8,84]$} \\
\hline Kenkey & Maize & L. fermentum, L. reuteri & Ghana & $\begin{array}{l}\text { Sourdough } \\
\text { Dumpling }\end{array}$ & {$[7,8]$} \\
\hline Khambir & Wheat & $\begin{array}{l}\text { Yeast, Mold, LAB, } \\
\text { Bifidobacterium sp. }\end{array}$ & W. Himalayas & Flat Bread & [85] \\
\hline Kishk & Wheat, Oats & $\begin{array}{c}\text { L. plantarum, L. brevis, Lactobacillus casei, } \\
\text { Bacillus subtilis, Yeasts } \\
\text { L. rhamnosus, Lactobacillus sakei }\end{array}$ & Egypt, Syria, Arabic Countries & Soup & [8] \\
\hline Kisra & Sorghum & $\begin{array}{c}\text { P. pentosaceus, Lactobacillus coprophilus, } \\
\text { Lactobacillus cellobiosus, L. brevis, L. } \\
\text { fermentum, L. amylovorus, Lactobacillus } \\
\text { reuteri, Candida intermedia, Debaryomyces } \\
\text { hansenii, } \\
\text { S. cerevisiae }\end{array}$ & Sudan & Pancake-Like & {$[8]$} \\
\hline Koko & Maize & L. plantarum, L. brevis & Ghana & Beverage & [7] \\
\hline Kvass & Rye & $\begin{array}{l}\text { L. casei, L. mesenteroides, } \\
\text { S. cerevisiae }\end{array}$ & Central Europe & Beverage & {$[8]$} \\
\hline
\end{tabular}


Table 2. Cont.

\begin{tabular}{|c|c|c|c|c|c|}
\hline Name & Cereal Used & Fermentation Microorganism (s) & Country/Region of Origin & $\begin{array}{l}\text { Type of } \\
\text { Product }\end{array}$ & Reference \\
\hline Kwunu-Zaki & Millet, Sorghum, Maize & LAB & Northern Nigeria & Beverage & [7] \\
\hline Liha & Maize & Unknown & Ghana, Togo, Benin, Nigeria & Beverage & [7] \\
\hline Mahewu & Millet, Sorghum, Maize & $\begin{array}{c}\text { L. delbrueckii, L. bulgaricus, Streptococcus } \\
\text { lactis }\end{array}$ & S. Africa, Togo & Beverage & {$[7,77]$} \\
\hline Mangisi & Millet & Unknown & Zimbabwe & Beverage & [7] \\
\hline Mawe & Maize & LAB & S. Africa, Togo & Dough & {$[7,8]$} \\
\hline Munkoyo & $\begin{array}{c}\text { Sorghum, Millet Or Maize Plus } \\
\text { Munkoyo Roots }\end{array}$ & Unknown & Zambia, Africa & Beverage & [7] \\
\hline Mutwiwa & Maize & LAB & Zimbabwe & Porridge & {$[7]$} \\
\hline Ogi, Ogi-Baba & Maize, Millet, Sorghum & L. plantarum & Nigeria, W. Africa & Pudding & {$[7,8]$} \\
\hline Pozol & Maize & $\begin{array}{c}\text { Streptococcus bovis, Streptococcus } \\
\text { macedonicus, L. lactis, Enterococcus } \\
\text { sulfureus, L. fermentum }\end{array}$ & Mexico, Guatemala & Beverage & [8] \\
\hline $\begin{array}{l}\text { Tarhana, } \\
\text { Trahana }\end{array}$ & $\begin{array}{c}\text { Wheat (Rye, Maize, Barley, Corn, } \\
\text { Oat, Buckwheat) }\end{array}$ & $\begin{array}{l}\text { L. bulgaricus, S. thermophilus, L. lactis, } \\
\text { Lactococcus diacetylactis, L. acidophilus, } \\
\text { Lactococcus cremoris, L. casei, S. cerevisiae }\end{array}$ & Greece, Cyprus, Turkey & Soup & [8] \\
\hline Tobwa & Maize & LAB & Zimbabwe & Beverage & [7] \\
\hline Togwa & Sorghum, Millet, Maize & Lactobacillus, Streptococcus & Tanzania & Beverage & {$[7,77]$} \\
\hline Uji & Maize, Millet, Sorghum & L. plantarum & Uganda, Kenya, Tanzania & Beverage & [7] \\
\hline Ricera & Rice & $\begin{array}{l}\text { S. thermophilus, L. acidophilus, L. } \\
\text { bulgaricus, Bifidobacterium bifidum }\end{array}$ & Unknown & Unknown & [76] \\
\hline Koozh & Millet, Rice & $\begin{array}{l}\text { L. } \\
\text { fermentum }\end{array}$ & S. India & Beverage & {$[77,86]$} \\
\hline Kunu & Maize, Millet, Sorghum & $\begin{array}{c}\text { Lactobacillus, Lactococcus, Leuconostoc, } \\
\text { Pediococcus, } \\
\text { Weissella }\end{array}$ & W. Africa & Beverage & [87] \\
\hline
\end{tabular}


Health Implications of Bacteria Obtained from Cereal-Based Fermented Foods

Many of the microbial species' strains found in fermented foods have been recognized to possess probiotic or health-promoting qualities. As a result, products containing adequate amounts of live cells of such strains may exert similar health benefits [3]. However, in vivo studies involving clinical trials are mandatory to confirm such assumptions; nevertheless, it should be highlighted that in some countries (e.g., Canada, Italy), lists of potential probiotic strains are included in regulatory guidelines, whereas in other countries (e.g., India), fermented foods with probiotic cultures are incorporated in dietary guidelines $[3,88]$.

Besides the fortification of fermented products with nutrients and other bioactives that were previously described (vitamins, phenolic compounds), fermenting microorganisms produce additional metabolites that may exert positive effects on various health-related conditions. The expression of the genes responsible for these metabolites depends on the microbial species, strain, and the matrix in which the microorganism is grown (the type of product). For example, a polysaccharide with anti-tumor activity was isolated after the in vitro fermentation of barley (sequential treatment of steamed ground barley grains with amylase hydrolysis, followed by yeast fermentation using S. cerevisiae, and then bacterial fermentation with Weissella cibaria). The polysaccharide was tested in vivo and showed antimetastatic properties through the promotion of NK cells' cytolytic activity and the activation of macrophages [89]. A L. brevis strain was also used to produce sourdough bread with anti-hypertensive properties. The strain was previously evaluated for its efficient production of $\gamma$-aminobutyric acid (GABA) and angiotensin-converting enzyme I (ACE). Both metabolites are related to the regulation of blood pressure [90].

\subsection{Prebiotic Potential of Cereal-Based Fermented Foods}

The most recent and refined definition of prebiotics was published by The International Scientific Association for Probiotics and Prebiotics (ISAPP) in an expert consensus document. The new definition expands the meaning of prebiotics from non-digestible oligosaccharides of food origin to "a substrate that is selectively utilized by host micro-organisms conferring a health benefit" [91]. In addition, the site of the host organism, where the beneficial bacteria may be located, is not limited to the human lower gastrointestinal tract (GIT), but also includes other targets such as skin, the whole GIT including the upperparts and mouth, as well as the urogenital tract [92]. Consequently, besides carbohydrates, other compounds could be considered to exert prebiotic effects, such as micronutrients (inorganic compounds), peptides, phenolics, and fatty acids [93].

Up to date, the investigated sources of prebiotic compounds are of plant origin from western countries, especially whole grains, fruit, and vegetables, i.e., wheat, barley, Jerusalem artichoke, leek, asparagus, garlic, onion, chicory root, and bananas. However, it is considered essential to explore a broader variety of raw materials and traditional products of eastern regions as potential novel prebiotic "pools" [91]. Fermented cereal-based products could be examined as promising sources of compounds with prebiotic effect since they may contain soluble fibers ( $\beta$-glucans and arabinoxylans and their oligomeric products), galacto-oligosaccharides (GOSs), fructo-oligosaccharides (FOSs), resistant starch, phenolics, peptides, etc., depending on the cereal that was employed as a substrate for their production and the extent of fermentation they have undergone $[93,94]$. Although there are a lack of reports regarding the prebiotic effect of fermented cereal products, recent studies demonstrate a substantial effect of cereals on human gut microbiota. Tamura et al. [95] studied the utilization mechanisms of mixed-linkage $\beta-(1,3) / \beta-(1,4)$-glucans (MLGs) by human gut Bacteroidetes (Bacteroides ovatus). Their findings emphasize the great importance of these commonly occurring polysaccharides in cereal grains for gut microbial metabolism. Structural differences (molecular characteristics) of arabinoxylans (AXs) derived from various cereals (corn, barley, wheat, rye, rice, and oat) and the impact of different extraction methods on molecular features of these polysaccharides have been discussed by Wang et al. [96]. It is worth mentioning that the gut microbial composition may change with an alteration on the arabinosyl substitutional position in the xylan backbone, implying a possible 
relation between the fine structure of the polymeric carbohydrate and the composition of the microbial community. An interesting opinion paper, published lately, summarizes the intervention studies on humans which report the effects of AXs and arabinoxylo-oligosaccharides (AXOS) on various metabolic parameters. Bread and bakery products (muffins, rolls) were used as the delivery matrix of AXs and AXOs in most cases [97]. Furthermore, the beneficial role of polyphenols, which were bound to fibers of whole-grain wheat, on the inflammation of people with suboptimal dietary and lifestyle behaviors has been confirmed. The replacement of refined wheat with whole-grain wheat for an 8-week period led to a significant increment of dihydroferulic acid (DHFA) and fecal ferulic acid (FA) and a bacterial community modification [98]. Both in vitro and in vivo studies showed the inhibitory effect of dextrins from maize starch on Firmicutes, a bacterial phylum which is related to obesity; i.e., the Firmicutes/Bacteroidetes (F/B) proportion is increased in obese people compared to lean people and tends to decrease with weight loss. In parallel, the growth of microbes belonging to Actinobacteria and Bacteroidetes was stimulated, indicating the beneficial role of dextrins in healthy gut microbiota. Clinical studies are mandatory to support all these assumptions $[99,100]$.

Besides the prebiotic fibers of the cereals, microorganisms used for fermentation may excrete such compounds. Currently, research studies focus on specific LAB (Leuconostoc, Lactobacillus, Streptococcus, Weissella) that produce long-chain extracellular sugar polymers (EPS). There is extensive research on the technological and functional attributes of these polysaccharides in bakery products [101]. For example, a recent study showed that EPS obtained from L. plantarum has a positive effect on the stalling and retrogradation of bread made from wheat sourdough when added at a $1.5 \%$ level [102]. Concerning the possible health-related benefits, only a few data are available. A wild-type strain of W. cibaria was used to produce a dextran with a high polymerization degree and the latter was assessed for its prebiotic potential compared to inulin. Batch fermentations using this dextran as a sole carbon source and fecal microorganisms as inoculum revealed the enhancement of Prevotella and Bacteroides populations and the increment of propionate production. Contrary to inulin, high DP dextran does not seem to stimulate bifidobacteria [103]. Wolter et al. [104] investigated the effect of flour type in sourdoughs on EPS production by W. cibaria MG1. Buckwheat, oat, quinoa, teff, as well as wheat flour were used as substrates to prepare sourdough fermented by the aforementioned strain. Low concentrations of fermentable sugars in oat did not favor the growth of the microorganism. The best results regarding the sourdough performance and EPS yields were obtained with buckwheat and quinoa flour, underlining the positive effects of $W$. cibaria on the production of high-quality gluten-free bread. The effect of fermentation substrate on EPS production was also investigated by Kajala et al. [105]. Two strains of Weissella confuse were used to ferment rye and wheat bran. The yield of the produced dextran was higher in the case of rye bran, which was attributed to the longer acidification lag phase compared to the wheat bran fermentation by both strains. An interesting approach to the preservation of the prebiotic content in gluten-free bread was recently published. Inulin is often incorporated in various foods to enhance their dietary fiber content, but also to exert other technological functionalities. Yet, the endogenous or added inulin content is reduced during the breadmaking process due to the activity of yeasts' invertase, which hydrolyzes fructans. In this context, Morreale et al. [106] investigated the effect of inulin's degree of polymerization as well as the use of yeasts with low invertase activity on the final inulin content and the technological characteristics of gluten-free bread made from rice flour. Bread made with the conventional baker's yeast presented an inulin loss of up to $40 \%$ (depending on the DP of the added inulin) after baking, whereas the respective losses reached only $5 \%$ for the bread made with the low invertase activity yeast.

Polyphenols also play an important role in the modulation of gut microbiota since only a low percentage (up to $10 \%$ ) of their daily intake is bioavailable, while the rest is led to the large intestine where the microbial population of the gut enzymically degrades these compounds [107]. Low-molecular-weight bioactive components are the result of such enzymic breakdown, which in turn alters the biodiversity of the gut microbiota and exerts health benefits for the host. It should be underlined though that the possible prebiotic and/or health-promoting effects of polyphenols are 
closely dependent on the individuals' gut microbiome [108]. Regarding the prebiotic effect of cereals' phenolic components, intervention studies with whole grain wheat and maize showed that bifidogenic bacteria and/or LAB were preferentially favored with limited or no changes in the numbers of the total gut microbial community. As whole-grain cereals are also rich sources of dietary fibers, it is controversial whether these effects were solely due to the phenolic compounds alone [109]. In an in vitro fermentation simulating the digestion from mouth to small intestine, Kristek et al. [110] studied the impact of $1 \%$ and $3 \%$ intake of oat bran, $\beta$-glucan extract, and polyphenol extracts separately. The results showed that the polyphenol mix increased the Enterobacteriaceae family within $24 \mathrm{~h}$, but the most significant impact (increment of bifidobacteria, enhanced production of propionic and acetic acid) on the gut microbiota was achieved with the digestion of oats and not by a single group of compounds; this implies a synergistic effect of the dietary fibers and polyphenols on gut microbiota and also points to the lack of energy for microbial growth in the case of using single compounds as substrates.

\subsection{Reduction of Antinutrients and Allergens}

Besides valuable nutrient compounds, cereals contain a notable number of components that are considered anti-nutritional factors (ANFs). These components include phytic acid/phytate (myoinositol-1,2,3,4,5,6-hexakis dihydrogen phosphate), tannins, and polyphenols [25]. Phytate or phytic acid is a secondary metabolite, found mainly in the aleurone layer and pericarp (wheat, rice) or in the endosperm (maize) of cereals, serving as their phosphorus repository. The content of phytate in cereals varies between $0.18 \mathrm{~g}$ to almost $6.5 \mathrm{~g}$ per $100 \mathrm{~g}$ product (dw) [111]. The presence of phytic acid plays a crucial role in the nutritional value of the food in which it is found as it has the ability to hinder enzymatic activity (trypsin and beta-galactosidase) and form chelates with metal ions, i.e., iron, magnesium, calcium, and zinc, thus reducing their bioavailability [112]. Likewise, tannins and polyphenols have a strong negative effect on protein digestibility since their hydroxyl groups form complexes with the carbonyl group of proteins. As a result, proteins precipitate, proteases are inhibited, and thereby, amino acid deprivation is realized when a diet is based on cereal products rich on polyphenols, which is the case in most developing countries or for people following a vegan dietary pattern $[7,23]$. Prolonged periods of these nutritional deficiencies may also lead to osteoporosis, iron deficiency anemia, and impairments of physical growth [113].

Among the technologies and strategies applied for ANFs reduction, fermentation is considered one of the most effective ones. Mineral binders were reduced by fermentation in togwa [114], sorghum porridges [115], and finger millet porridges [51]. Phytic acid can be degraded by endogenous or microbial phytases during natural fermentation and increase the bioavailable amount of iron, calcium, and zinc. The value of $\mathrm{pH}$ encountered for fermented products is considered optimal for the enzymes to act against phytate $[111,112,116]$. Wet and solid-state fermentation of various cereals and their brans have been studied considering the physicochemical alteration of the products and the effect on dephytinization. Spaggiari et al. [45] investigated the use of L. rhamnosus 1473 strain in a solid-state lactic acid fermentation of wheat bran to increase its nutritional profile. Indeed, phytic acid decreased to $36.4 \%$ due to the fermentation process. Similar findings were also reported by Zhao et al. [47], where over $20 \%$ of the phytic acid contained in the wheat bran was degraded using yeast and LAB solid-state fermentation. In both research approaches, high temperatures were applied as pretreatment methods and therefore endogenous phytases are believed to be deactivated. The authors concluded that dephytinization could be attributed exclusively to microbial phytases. Phytic acid degradation has also been studied in other cereal-based fermented products. Lactobacillus sanfrancisco CCM 7699, L. plantarum CCM 7039, L. amylovorus CCM 4380, and L. plantarum CCM 7039 were used for fermentation of wheat flour in two tarhana samples, boza, oat, and rice beverages, respectively. Over $80 \%$ of phytic acid was degraded in both tarhana samples after $144 \mathrm{~h}$ of fermentation (6 days is the mean time needed for tarhana preparation), while complete degradation was observed after $10 \mathrm{~h}$ of fermentation in all fermented beverages [117]. Recently, the effect of fermentation's temperature on phytic acid degradation and the mineral content in whole-wheat sourdough bread was reported. A combination 
of starter cultures (Lactobacillus sp.) at the lowest tested temperature $\left(25^{\circ} \mathrm{C}\right)$ gave the best results concerning nutritional value and sensory properties [118]. Furthermore, pseudo-cereals have also been reported to benefit from fermentation regarding the bioavailability of their minerals. Quinoa, canihua, and amaranth flours following fermentation exhibited improved accessibility of iron, calcium, and zinc compared to their raw counterparts [119].

The synergistic effect of seed germination and fermentation on nutritional and functional aspects has been explored by Montemurro et al. [27]. Among other raw materials, wheat, barley, and quinoa were subjected to germination, drying, and milling. The flours were then used to prepare sourdough bread. Flours obtained after seed sprouting were characterized by lower phytate and tannin content, whereas the produced bread showed higher protein digestibility compared to conventional wheat flour bread. The tannin content was reduced by $30-39 \%$ in grain sorghum using fermentation, steaming, and flaking processing, indicating the amelioration of the biological value of sorghum protein compared to control samples [120].

An equally important issue is the reduction of cereal allergenicity through the fermentation process. Food allergies are a globally major concern since they seem to affect almost $5 \%$ of adults and $8 \%$ of children under 18 years [121]. In general, all food proteins may cause allergic reactions; however, gluten proteins from wheat and related grains (barley, rye, and possibly oat) are considered to be among the most common sources that trigger allergies [122]. More specifically, gliadins $(\alpha-, \beta-, \gamma-, \omega-)$, low molecular glutenins (LMW), high molecular glutenins (HMW), and the albumin/globulin fractions are involved in the mechanism (IgE-dependent) that induces cereal allergenicity [123]. It should be emphasized that celiac disease (CD), also known as celiac sprue and gluten-sensitive enteropathy, differs from a cereal proteins allergy and is rather a food intolerance, encountered in almost 1 out of 100-300 Caucasian individuals worldwide. Celiac disease (an autoimmune disorder) is characterized as an inflammatory disease of the upper small intestine in genetically predisposed persons triggered by the consumption of products that contain gluten $[123,124]$. Hydrolysis of proteins by microbial or endogenous proteases and peptidases, occurring during fermentation, may result in diminished allergic reactions through the degradation of the respective antigenic epitopes [19]. Although there are many reports regarding the technological properties and nutritional enhancement of cereal-based products after fermentation, current research concerning the effects of this ancient process on their allergens is rather limited. Di Cagno et al. [125] prepared a sourdough bread, which was made from wheat and a mixture of non-toxic flours from oat, millet, and buckwheat. As starter microorganisms, selected strains of lactic acid bacteria (Lactobacillus alimentarius 15M, L. brevis 14G, L. sanfranciscensis 7A, and Lactobacillus hilgardii 51B) were used based on their ability to hydrolyze gliadin fractions. The same research group performed a pilot study with young celiac disease patients. They showed that bakery products made from wheat flour and the aforementioned microbial strains are non-toxic to $C D$ patients [126].

An in vivo study with CD patients was performed and results showed that the consumption of bread with the selected bacteria and nontoxic flours did not affect intestinal permeability. Moreover, an in vitro study examined the effect of sourdough lactic acid bacteria on IgE-binding proteins in bread made from wheat and rye flours. Compared to control samples (bread made with baker's yeast), the tested products showed that the IgE-reactive epitopes were significantly decreased [127]. The capacity of VSL\#3 (a mixture of probiotic strains) to ferment wheat flour and reduce its toxicity was investigated. The findings indicated that gliadins were degraded to a large extent, meaning that these microorganisms could be used as effective cultures for sourdough preparation [128]. It appears that during fermentation of sourdough by Lactobacillus sp., gluten's disulphide bonds are reduced, which further enhances the enzymatic activity of cereal proteases and hence, gluten digestibility is improved $[129,130]$. 


\section{Effect of Cereal-Based Fermented Foods' Components on Gut Microbiota}

Gut microbiota contributes to a wide spectrum of human health aspects. These numerous and variable microbial species (bacteria, viruses, archaea, eukaryotes) may reach $10^{14}$ cells in the gut and their composition can be affected by genetic factors, lifestyle, diet, stress, diseases, and the use of pharmaceutical products [131-133]. A beneficial, stable, and well-balanced composition is crucial for the maintenance of immune equilibrium, the integrity of the gut epithelial cells, and inflammation prevention. Dysbiosis of the gut ecosystem is associated with intestine related diseases like IBS, skin inflammation (psoriasis, atopic dermatitis), cardiovascular diseases, cancer, obesity, mental health, arthritis, and type II diabetes [2].

Currently, the available intervention studies regarding fermented cereal-based products focus on the impacts of sourdough bread on specific GI diseases as bread is one of the most consumed products around the globe [134]. Therefore, there are no published data yet on the ways that cereal-based fermented foods may act on human gut microbiota and the possible modifications that they may cause on the species' dynamics. On account of this, scientific evidence of specific food components and their impact on human gut microbial consortium will be shortly discussed herein.

Fermented products in general and cereal-based foods in particular are characterized by an abundance of ingredients that reach the GI tract and are accessible by the gut microorganisms of the host. These ingredients include macronutrients such as carbohydrates and proteins, micronutrients like vitamins, phenolic compounds, and minerals, but also bacterial components from the fermentation cultures, biogenic metabolites (organic acids, biogenic amines, etc.), or even live microorganisms (probiotics) that interact with the human microflora located in the gut [135].

The daily intake of fermented food and beverages ranges between $5 \%$ and $40 \%$ depending on the geographic area. Viable bacteria from fermented foods along with foodborne microbes from other food sources may reach up to $1.0 \%$ of the commensal gut microbiota $\left(10^{10}\right.$ to $10^{11}$ ingested bacteria per day). These transient microorganisms are eliminated through feces, but can also adhere to the GI tract and eventually alter the gut microbial composition [2,131]. Fermented foods enrich the diverse intestinal microbiome, mainly with gram-positive bacteria belonging to the Firmicutes and Actinobacteria phyla, such as Lactobacilli, Lactococci, Streptococci, Enterococci, Carnobacteria, Bifidobacteria, Brevibacteria, and Propionibacteria, and some yeast and fungi species (Saccharomyces, Kluyveromyces, Debaryomyces, Penicilium, etc). Subsequently, dietary habits may exhibit a strong effect on intestinal bacterial dynamics through the consumption of various viable microorganisms. The latter could have an inhibitory or stimulating effect on the gut autochthonous species [2,136].

Dietary choices may also alter the microbial balances in the gut, as is evident from data obtained from clinical studies testing various diets (western, plant-based, meat-based, Mediterranean, vegan, and vegetarian) [137]. Animal-based diets (low fiber content and high animal protein and fat) seem to decrease the population of Firmicutes and on the contrary, increase bile-tolerant species (Alistipes, Bilophila, and Bacteroides) [136]. Likewise, gluten-free diets increased the numbers of Enterobacteriaceae, i.e., E.coli and other potentially pathogenic bacteria [138]. Conversely, diets based on plant-based foods (vegan, vegetarian) or balanced diets (Mediterranean) were linked with higher counts on "beneficial" bacteria (Lactobacillus sps. and Bifidobacterium sps.) [139]. It should also be mentioned that these diets include elevated daily intakes of fibers, a better ratio of mono- and poly-unsaturated to saturated fatty acids (compared to animal food-based diets), and a variety of antioxidant compounds [137].

\section{Concluding Remarks and Future Perspectives}

Fermentation, a traditional food processing technology, is gaining attention again due to the recognition of significant benefits it delivers to the products. Furthermore, since it has low energy requirements and no complicated equipment is needed, it is considered a viable solution for developing countries to support local economies, valorize local raw materials, and provide products with valuable compounds as a solution to malnutrition. To surpass the safety issues that may occur from the lack of training, proper facilities, low quality of local resources, and problems in the logistics chain 
(from production to consumption), a standardized procedure for each "traditional" product must be determined and selected starter cultures should be used, following optimization strategies for all parameters affecting the outcome of the fermentation process. Microbial domestication and technological properties of the selected strains are considered crucial and therefore, should be studied thoroughly to be proposed for large or domestic scale efficient production of fermented cereal products.

The present review covers the recent literature regarding the main nutritional aspects of cereal-based fermented foods (Figure 2).

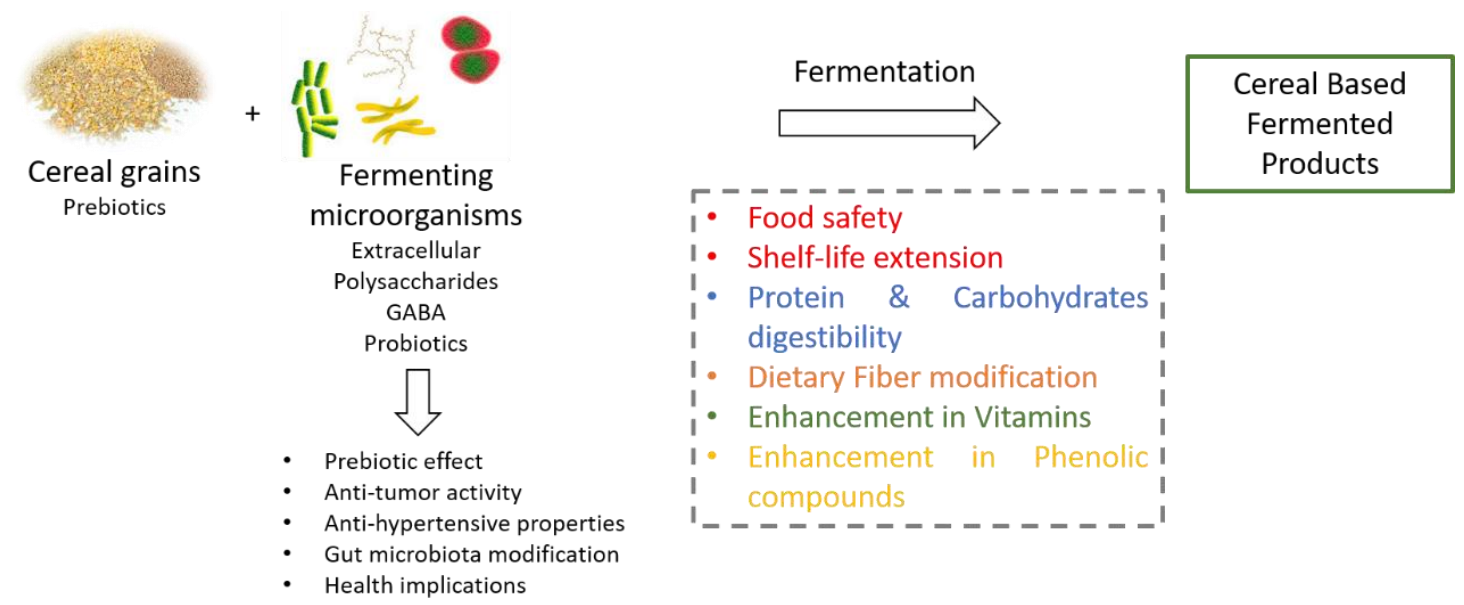

Figure 2. Schematic diagram of the main effects of fermentation on cereal-based products.

The effects of fermentation on protein and carbohydrate digestibility, reduction of antinutrients and allergens, and enhancement in phenolic compounds and vitamins are discussed. In addition, the role of cereal-based fermented products as probiotic carriers as well as their prebiotic potential is presented. The aspect of each trait on human health promotion and well-being is presented in the respective section. Technological implications of fermentation on the properties of end products, such as the impact on food safety and shelf-life extension, along with modifications on the nature and content of specific compounds are reviewed.

Although there is sufficient evidence for the positive contribution of these products in human health, including alleviation of medical disorders, there is a need to unravel the underlying mechanisms. This must proceed by properly designed clinical studies to evaluate in-depth possible cause and effect relationships, involving physiological responses linked with chronic diseases. Meticulous data interpretation will be needed to establish the position of cereal-based fermented products in national dietary guidelines and provide useful information for tailored functional foods production. The latter would not only meet the growing demand of consumers in developed countries for healthier or "natural" foods, but will also lighten the burden of hunger and undernourishment in many developing countries.

Author Contributions: Conceptualization, P.T., A.-M.M. and C.G.B.; validation, A.-M.M. and C.G.B.; investigation, P.T.; writing—original draft preparation, P.T.; writing—review and editing, C.G.B., A.-M.M. and P.T.; visualization, P.T.; supervision, C.G.B. and A.-M.M.; funding acquisition, C.G.B. All authors have read and agreed to the published version of the manuscript.

Funding: The corresponding author wishes to acknowledge the financial support of this work by the project "Research Infrastructure on Food Bioprocessing Development and Innovation Exploitation-Food Innovation RI" (MIS 5027222), which is implemented under the Action "Reinforcement of the Research and Innovation Infrastructure", funded by the Operational Program "Competitiveness, Entrepreneurship and Innovation" (NSRF 2014- 2020) and co-financed by Greece and the European Union (European Regional Development Fund).

Conflicts of Interest: The authors declare no conflict of interest. 


\section{References}

1. Chaves-López, C.; Serio, A.; Grande-Tovar, C.D.; Cuervo-Mulet, R.; Delgado-Ospina, J.; Paparella, A. Traditional Fermented Foods and Beverages from a Microbiological and Nutritional Perspective: The Colombian Heritage. Compr. Rev. Food Sci. Food Saf. 2014, 13, 1031-1048. [CrossRef]

2. Plé, C.; Breton, J.; Daniel, C.; Foligné, B. Maintaining gut ecosystems for health: Are transitory food bugs stowaways or part of the crew? Int. J. Food Microbiol. 2015, 213, 139-143. [CrossRef] [PubMed]

3. Marco, M.L.; Heeney, D.; Binda, S.; Cifelli, C.J.; Cotter, P.D.; Foligné, B.; Gänzle, M.; Kort, R.; Pasin, G.; Pihlanto, A.; et al. Health benefits of fermented foods: Microbiota and beyond. Curr. Opin. Biotechnol. 2017, 44, 94-102. [CrossRef] [PubMed]

4. Blandino, A.; Al-Aseeri, M.E.; Pandiella, S.S.; Cantero, D.; Webb, C. Cereal-based fermented foods and beverages. Food Res. Int. 2003, 36, 527-543. [CrossRef]

5. USDA Nutrient Database for Standard Reference. Available online: https://fdc.nal.usda.gov/ (accessed on 20 May 2020).

6. Wuyts, S.; Van Beeck, W.; Allonsius, C.N.; van den Broek, M.F.L.; Lebeer, S. Applications of plant-based fermented foods and their microbes. Curr. Opin. Biotechnol. 2020, 61, 45-52. [CrossRef] [PubMed]

7. Nyanzi, R.; Jooste, P.J. Cereal-Based Functional Foods; Probiotics, Everlon Cid Rigobelo, IntechOpen: Rijeka, Croatia, 2012. [CrossRef]

8. Kohajdová, Z. Fermented cereal products. In Current Developments in Biotechnology and Bioengineering; Elsevier: Amsterdam, The Netherlands, 2017; pp. 91-117.

9. Peyer, L.C.; Zannini, E.; Arendt, E.K. Lactic acid bacteria as sensory biomodulators for fermented cereal-based beverages. Trends Food Sci. Technol. 2016, 54, 17-25. [CrossRef]

10. Brückner-Gühmann, M.; Banovic, M.; Drusch, S. Towards an increased plant protein intake: Rheological properties, sensory perception and consumer acceptability of lactic acid fermented, oat-based gels. Food Hydrocoll. 2019, 96, 201-208. [CrossRef]

11. Salmerón, I.; Thomas, K.; Pandiella, S.S. Effect of potentially probiotic lactic acid bacteria on the physicochemical composition and acceptance of fermented cereal beverages. J. Funct. Foods 2015, 15, 106-115. [CrossRef]

12. Awobusuyi, T.D.; Siwela, M. Nutritional Properties and Consumer's Acceptance of Provitamin A-Biofortified Amahewu Combined with Bambara (Vigna Subterranea) Flour. Nutrients 2019, 11, 1476. [CrossRef]

13. Akissoé, N.H.; Sacca, C.; Declemy, A.-L.; Bechoff, A.; Anihouvi, V.B.; Dalodé, G.; Pallet, D.; Fliedel, G.; Mestres, C.; Hounhouigan, J.D.; et al. Cross-cultural acceptance of a traditional yoghurt-like product made from fermented cereal. J. Sci. Food Agric. 2015, 95, 1876-1884. [CrossRef]

14. Adebiyi, J.A.; Kayitesi, E.; Adebo, O.A.; Changwa, R.; Njobeh, P.B. Food fermentation and mycotoxin detoxification: An African perspective. Food Control 2019, 106, 106731. [CrossRef]

15. Juodeikiene, G.; Bartkiene, E.; Cernauskas, D.; Cizeikiene, D.; Zadeike, D.; Lele, V.; Bartkevics, V. Antifungal activity of lactic acid bacteria and their application for Fusarium mycotoxin reduction in malting wheat grains. LWT 2018, 89, 307-314. [CrossRef]

16. Adebo, O.A.; Kayitesi, E.; Njobeh, P.B. Reduction of Mycotoxins during Fermentation of Whole Grain Sorghum to Whole Grain Ting (a Southern African Food). Toxins 2019, 11, 180. [CrossRef] [PubMed]

17. Ezekiel, C.N.; Abia, W.A.; Ogara, I.M.; Sulyok, M.; Warth, B.; Krska, R. Fate of mycotoxins in two popular traditional cereal-based beverages (kunu-zaki and pito) from rural Nigeria. LWT Food Sci. Technol. 2015, 60, 137-141. [CrossRef]

18. Ogunremi, O.R.; Banwo, K.; Sanni, A.I. Starter-culture to improve the quality of cereal-based fermented foods: Trends in selection and application. Curr. Opin. Food Sci. 2017, 13, 38-43. [CrossRef]

19. Shiferaw Terefe, N.; Augustin, M.A. Fermentation for tailoring the technological and health related functionality of food products. Crit. Rev. Food Sci. Nutr. 2019, 1-27. [CrossRef]

20. M'hir, S.; Minervini, F.; Di Cagno, R.; Chammem, N.; Hamdi, M. Technological, functional and safety aspects of enterococci in fermented vegetable products: A mini-review. Ann. Microbiol. 2012, 62, 469-481. [CrossRef]

21. Adesulu-Dahunsi, A.T.; Jeyaram, K.; Sanni, A.I. Probiotic and technological properties of exopolysaccharide producing lactic acid bacteria isolated from cereal-based nigerian fermented food products. Food Control 2018, 92, 225-231. [CrossRef] 
22. Xu, Y.; Zhou, T.; Tang, H.; Li, X.; Chen, Y.; Zhang, L.; Zhang, J. Probiotic potential and amylolytic properties of lactic acid bacteria isolated from Chinese fermented cereal foods. Food Control 2020, 111, 107057. [CrossRef]

23. Joye, I. Protein Digestibility of Cereal Products. Foods 2019, 8, 199. [CrossRef]

24. Fan, P.; Li, L.; Rezaei, A.; Eslamfam, S.; Che, D.; Ma, X. Metabolites of dietary protein and peptides by intestinal microbes and their impacts on gut. Curr. Protein Pept. Sci. 2015, 16, 646-654. [CrossRef] [PubMed]

25. Melini, F.; Melini, V.; Luziatelli, F.; Ficca, A.G.; Ruzzi, M. Health-Promoting Components in Fermented Foods: An Up-to-Date Systematic Review. Nutrients 2019, 11, 1189. [CrossRef] [PubMed]

26. Kostekli, M.; Karakaya, S. Protease inhibitors in various flours and breads: Effect of fermentation, baking and in vitro digestion on trypsin and chymotrypsin inhibitory activities. Food Chem. 2017, 224, 62-68. [CrossRef] [PubMed]

27. Montemurro, M.; Pontonio, E.; Gobbetti, M.; Giuseppe, C. International Journal of Food Microbiology Investigation of the nutritional, functional and technological effects of the sourdough fermentation of sprouted flours. Int. J. Food Microbiol. 2019, 302, 47-58. [CrossRef] [PubMed]

28. Ogodo, A.C.; Ugbogu, O.C.; Onyeagba, R.A.; Okereke, H.C. Microbiological quality, proximate composition and in vitro starch/protein digestibility of Sorghum bicolor flour fermented with lactic acid bacteria consortia. Chem. Biol. Technol. Agric. 2019, 6, 7. [CrossRef]

29. Simwaka, J.E.; Chamba, M.V.M.; Huiming, Z.; Masamba, K.G.; Luo, Y. Effect of fermentation on physicochemical and antinutritional factors of complementary foods from millet, sorghum, pumpkin and amaranth seed flours. Int. Food Res. J. 2017, 24, 1869.

30. Lorusso, A.; Verni, M.; Montemurro, M.; Coda, R.; Gobbetti, M.; Rizzello, C.G. Use of fermented quinoa flour for pasta making and evaluation of the technological and nutritional features. LWT 2017, 78, 215-221. [CrossRef]

31. Chaves-López, C.; Rossi, C.; Maggio, F.; Paparella, A.; Serio, A. Changes Occurring in Spontaneous Maize Fermentation: An Overview. Fermentation 2020, 6, 36. [CrossRef]

32. Gravina, A.G.; Dallio, M.; Romeo, M.; Di Somma, A.; Cotticelli, G.; Loguercio, C.; Federico, A. Adherence and Effects Derived from FODMAP Diet on Irritable Bowel Syndrome: A Real Life Evaluation of a Large Follow-Up Observation. Nutrients 2020, 12, 928. [CrossRef]

33. Zannini, E.; Arendt, E.K. Low FODMAPs and gluten-free foods for irritable bowel syndrome treatment: Lights and shadows. Food Res. Int. 2018, 110, 33-41. [CrossRef]

34. Biesiekierski, J.R.; Rosella, O.; Rose, R.; Liels, K.; Barrett, J.S.; Shepherd, S.J.; Gibson, P.R.; Muir, J.G. Quantification of fructans, galacto-oligosacharides and other short-chain carbohydrates in processed grains and cereals. J. Hum. Nutr. Diet. 2011, 24, 154-176. [CrossRef] [PubMed]

35. Chumpitazi, B.P.; Lim, J.; McMeans, A.R.; Shulman, R.J.; Hamaker, B.R. Evaluation of FODMAP carbohydrates content in selected foods in the United States. J. Pediatr. 2018, 199, 252-255. [CrossRef] [PubMed]

36. Ispiryan, L.; Zannini, E.; Arendt, E.K. Characterization of the FODMAP-profile in Cereal-product Ingredients. J. Cereal Sci. 2020, 92, 102916. [CrossRef]

37. Riaz, Q.; Ács, K.; Bekes, F.; Eastwood, R.F.; Farahnaky, A.; Majzoobi, M.; Blanchard, C.L. Fructan Contents in Australian Wheat Varieties Released Over the Last 150 Years. Cereal Res. Commun. 2019, 47, 669-677. [CrossRef]

38. Struyf, N.; Laurent, J.; Verspreet, J.; Verstrepen, K.J.; Courtin, C.M. Saccharomyces cerevisiae and Kluyveromyces marxianus cocultures allow reduction of fermentable oligo-, di-, and monosaccharides and polyols levels in whole wheat bread. J. Agric. Food Chem. 2017, 65, 8704-8713. [CrossRef]

39. Menezes, L.A.A.; Minervini, F.; Filannino, P.; Sardaro, M.L.S.; Gatti, M.; Lindner, J.D.D. Effects of sourdough on FODMAPs in bread and potential outcomes on irritable bowel syndrome patients and healthy subjects. Front. Microbiol. 2018, 9, 1972. [CrossRef] [PubMed]

40. Fraberger, V.; Call, L.-M.; Domig, K.J.; D'Amico, S. Applicability of yeast fermentation to reduce fructans and other FODMAPs. Nutrients 2018, 10, 1247. [CrossRef] [PubMed]

41. Yegin, S.; Kopec, A.; Kitts, D.D.; Zawistowski, J. Chapter 24-Dietary fiber: A functional food ingredient with physiological benefits. In Salt and Fat in Human Health; Preuss, H.G., Bagchi, D., Eds.; Academic Press: Cambridge, MA, USA, 2020; pp. 531-555. ISBN 978-0-12-816918-6.

42. Bach Knudsen, K.E.; Nørskov, N.P.; Bolvig, A.K.; Hedemann, M.S.; Lærke, H.N. Dietary fibers and associated phytochemicals in cereals. Mol. Nutr. Food Res. 2017, 61, 1600518. [CrossRef] [PubMed] 
43. Poutanen, K.S. Cereal raw material pretreatment. In Breakfast Cereals and How They Are Made; Elsevier: Amsterdam, The Netherlands, 2020; pp. 97-107.

44. Xiao, X.; Tan, C.; Sun, X.; Zhao, Y.; Zhang, J.; Zhu, Y.; Bai, J.; Dong, Y.; Zhou, X. Effects of fermentation on structural characteristics and in vitro physiological activities of barley $\beta$-glucan. Carbohydr. Polym. 2020, 231. [CrossRef] [PubMed]

45. Spaggiari, M.; Ricci, A.; Calani, L.; Bresciani, L.; Neviani, E.; Dall'Asta, C.; Lazzi, C.; Galaverna, G. Solid state lactic acid fermentation: A strategy to improve wheat bran functionality. LWT 2020, 118, 108668. [CrossRef]

46. Liu, N.; Ma, S.; Li, L.; Wang, X. Study on the effect of wheat bran dietary fiber on the rheological properties of dough. Grain Oil Sci. Technol. 2019, 2, 1-5. [CrossRef]

47. Zhao, H.-M.; Guo, X.-N.; Zhu, K.-X. Impact of solid state fermentation on nutritional, physical and flavor properties of wheat bran. Food Chem. 2017, 217, 28-36. [CrossRef] [PubMed]

48. Mihhalevski, A.; Nisamedtinov, I.; Hälvin, K.; Ošeka, A.; Paalme, T. Stability of B-complex vitamins and dietary fiber during rye sourdough bread production. J. Cereal Sci. 2013, 57, 30-38. [CrossRef]

49. Zhang, H.; Wang, H.; Cao, X.; Wang, J. Preparation and modification of high dietary fiber flour: A review. Food Res. Int. 2018, 113, 24-35. [CrossRef] [PubMed]

50. Gan, R.Y.; Li, H.B.; Gunaratne, A.; Sui, Z.Q.; Corke, H. Effects of Fermented Edible Seeds and Their Products on Human Health: Bioactive Components and Bioactivities. Compr. Rev. Food Sci. Food Saf. 2017, 16, 489-531. [CrossRef]

51. Gabaza, M.; Shumoy, H.; Louwagie, L.; Muchuweti, M.; Vandamme, P.; Du Laing, G.; Raes, K. Traditional fermentation and cooking of finger millet: Implications on mineral binders and subsequent bioaccessibility. J. Food Compos. Anal. 2018, 68, 87-94. [CrossRef]

52. Bationo, F.; Humblot, C.; Songré-Ouattara, L.T.; Hama-Ba, F.; Le Merrer, M.; Chapron, M.; Kariluoto, S.; Hemery, Y.M. Total folate in West African cereal-based fermented foods: Bioaccessibility and influence of processing. J. Food Compos. Anal. 2020, 85, 103309. [CrossRef]

53. Saubade, F.; Hemery, Y.M.; Guyot, J.-P.; Humblot, C. Lactic acid fermentation as a tool for increasing the folate content of foods. Crit. Rev. Food Sci. Nutr. 2017, 57, 3894-3910. [CrossRef]

54. Chandrasekar Rajendran, S.C.; Chamlagain, B.; Kariluoto, S.; Piironen, V.; Saris, P.E.J. Biofortification of riboflavin and folate in idli batter, based on fermented cereal and pulse, by Lactococcus lactis N8 and Saccharomyces boulardii SAA 655. J. Appl. Microbiol. 2017, 122, 1663-1671. [CrossRef]

55. Capozzi, V.; Menga, V.; Digesu, A.M.; De Vita, P.; van Sinderen, D.; Cattivelli, L.; Fares, C.; Spano, G. Biotechnological production of vitamin B2-enriched bread and pasta. J. Agric. Food Chem. 2011, 59, 8013-8020. [CrossRef]

56. Carrizo, S.L.; de Oca, C.E.M.; Laiño, J.E.; Suarez, N.E.; Vignolo, G.; LeBlanc, J.G.; Rollán, G. Ancestral Andean grain quinoa as source of lactic acid bacteria capable to degrade phytate and produce B-group vitamins. Food Res. Int. 2016, 89, 488-494. [CrossRef] [PubMed]

57. Chamlagain, B.; Deptula, P.; Edelmann, M.; Kariluoto, S.; Grattepanche, F.; Lacroix, C.; Varmanen, P.; Piironen, V. Effect of the lower ligand precursors on vitamin B12 production by food-grade Propionibacteria. LWT Food Sci. Technol. 2016, 72, 117-124. [CrossRef]

58. Xie, C.; Coda, R.; Chamlagain, B.; Varmanen, P. Co-fermentation of Propionibacterium freudenreichii and Lactobacillus brevis in Wheat Bran for in situ Production of Vitamin B12. Front. Microbiol. 2019, 10, 1541. [CrossRef] [PubMed]

59. Greppi, A.; Hemery, Y.; Berrazaga, I.; Almaksour, Z.; Humblot, C. Ability of lactobacilli isolated from traditional cereal-based fermented food to produce folate in culture media under different growth conditions. LWT 2017, 86, 277-284. [CrossRef]

60. Verni, M.; Verardo, V.; Rizzello, C.G. How Fermentation Affects the Antioxidant Properties of Cereals and Legumes. Foods 2019, 8, 362. [CrossRef]

61. Pozzo, L.; Vizzarri, F.; Ciardi, M.; Nardoia, M.; Palazzo, M.; Casamassima, D.; Longo, V. The effects of fermented wheat powder (Lisosan $\mathrm{G}$ ) on the blood lipids and oxidative status of healthy rabbits. Food Chem. Food Chem. Toxicol. 2015, 84, 1-7. [CrossRef]

62. Antognoni, F.; Mandrioli, R.; Potente, G.; Taneyo Saa, D.L.; Gianotti, A. Changes in carotenoids, phenolic acids and antioxidant capacity in bread wheat doughs fermented with different lactic acid bacteria strains. Food Chem. 2019, 292, 211-216. [CrossRef] 
63. Skrajda-Brdak, M.; Konopka, I.; Tańska, M.; Czaplicki, S. Changes in the content of free phenolic acids and antioxidative capacity of wholemeal bread in relation to cereal species and fermentation type. Eur. Food Res. Technol. 2019, 245, 2247-2256. [CrossRef]

64. Martini, D.; Taddei, F.; Nicoletti, I.; Ciccoritti, R.; Corradini, D.; D’Egidio, M.G. Effects of genotype and environment on phenolic acids content and total antioxidant capacity in durum wheat. Cereal Chem. 2014, 91, 310-317. [CrossRef]

65. Acosta-Estrada, B.A.; Gutiérrez-Uribe, J.A.; Serna-Saldívar, S.O. Bound phenolics in foods, a review. Food Chem. 2014, 152, 46-55. [CrossRef]

66. Balli, D.; Bellumori, M.; Pucci, L.; Gabriele, M.; Longo, V.; Paoli, P.; Melani, F.; Mulinacci, N.; Innocenti, M. Does Fermentation Really Increase the Phenolic Content in Cereals? Study Millet Foods 2020, 9, 303. [CrossRef]

67. Rollán, G.C.; Gerez, C.L.; LeBlanc, J.G. Lactic Fermentation as a Strategy to Improve the Nutritional and Functional Values of Pseudocereals. Front. Nutr. 2019, 6, 98. [CrossRef] [PubMed]

68. Balli, D.; Bellumori, M.; Paoli, P.; Pieraccini, G.; Di Paola, M.; De Filippo, C.; Di Gioia, D.; Mulinacci, N.; Innocenti, M. Study on a fermented whole wheat: Phenolic content, activity on PTP1B enzyme and in vitro prebiotic properties. Molecules 2019, 24, 1120. [CrossRef] [PubMed]

69. Rizzello, C.G.; Lorusso, A.; Montemurro, M.; Gobbetti, M. Use of sourdough made with quinoa (Chenopodium quinoa) flour and autochthonous selected lactic acid bacteria for enhancing the nutritional, textural and sensory features of white bread. Food Microbiol. 2016, 56, 1-13. [CrossRef] [PubMed]

70. Cui, L.; Li, D.; Liu, C. Effect of fermentation on the nutritive value of maize. Int. J. Food Sci. Technol. 2012, 47, 755-760. [CrossRef]

71. Cai, S.; Gao, F.; Zhang, X.; Wang, O.; Wu, W.; Zhu, S.; Zhang, D.; Zhou, F.; Ji, B. Evaluation of $\gamma$-aminobutyric acid, phytate and antioxidant activity of tempeh-like fermented oats (Avena sativa L.) prepared with different filamentous fungi. J. Food Sci. Technol. 2014, 51, 2544-2551. [CrossRef]

72. Aprodu, I.; Bolea, C.; Banu, I. Effect of lactic fermentation on nutritional potential of multigrain flours based on wheat, rye and oat. Ann. Univ. Dunarea Jos Galati. Fascicle VI Food Technol. 2019, 43. [CrossRef]

73. Çelik, E.E.; Gökmen, V. Effects of fermentation and heat treatments on bound-ferulic acid content and total antioxidant capacity of bread crust-like systems made of different whole grain flours. J. Cereal Sci. 2020, 93, 102978. [CrossRef]

74. Soycan, G.; Schär, M.Y.; Kristek, A.; Boberska, J.; Alsharif, S.N.S.; Corona, G.; Shewry, P.R.; Spencer, J.P.E. Composition and content of phenolic acids and avenanthramides in commercial oat products: Are oats an important polyphenol source for consumers? Food Chem. X 2019, 3, 100047. [CrossRef]

75. Călinoiu, L.F.; Cătoi, A.-F.; Vodnar, D.C. Solid-state yeast fermented wheat and oat bran as a route for delivery of antioxidants. Antioxidants 2019, 8, 372. [CrossRef]

76. Adebo, O.A.; Gabriela Medina-Meza, I. Impact of Fermentation on the Phenolic Compounds and Antioxidant Activity of Whole Cereal Grains: A Mini Review. Molecules 2020, 25, 927. [CrossRef] [PubMed]

77. Panghal, A.; Janghu, S.; Virkar, K.; Gat, Y.; Kumar, V.; Chhikara, N. Potential non-dairy probiotic products-A healthy approach. Food Biosci. 2018, 21, 80-89. [CrossRef]

78. Notarnicola, B.; Tassielli, G.; Renzulli, P.A.; Castellani, V.; Sala, S. Environmental impacts of food consumption in Europe. J. Clean. Prod. 2017, 140, 753-765. [CrossRef]

79. Ranadheera, C.S.; Vidanarachchi, J.K.; Rocha, R.S.; Cruz, A.G.; Ajlouni, S. Probiotic delivery through fermentation: Dairy vs. non-dairy beverages. Fermentation 2017, 3, 67. [CrossRef]

80. Vinderola, G.; Burns, P.; Reinheimer, J. Probiotics in Nondairy Products; Elsevier: Amsterdam, The Netherlands, 2017; ISBN 9780128039694.

81. Fekri, A.; Torbati, M.; Khosrowshahi, A.Y.; Shamloo, H.B.; Azadmard-Damirchi, S. Functional effects of phytate-degrading, probiotic lactic acid bacteria and yeast strains isolated from Iranian traditional sourdough on the technological and nutritional properties of whole wheat bread. Food Chem. 2020, 306, 125620. [CrossRef] [PubMed]

82. Binitu Worku, B.; Gemede, H.F.; Woldegiorgis, A.Z. Nutritional and alcoholic contents of cheka: A traditional fermented beverage in Southwestern Ethiopia. Food Sci. Nutr. 2018, 6, 2466-2472. [CrossRef]

83. Bassi, D.; Orrù, L.; Vasquez, J.C.; Cocconcelli, P.S.; Fontana, C. Peruvian chicha: A focus on the microbial populations of this ancient Maize-based fermented beverage. Microorganisms 2020, 8, 93. [CrossRef]

84. Tamene, A.; Kariluoto, S.; Baye, K.; Humblot, C. Quantification of folate in the main steps of traditional processing of tef injera, a cereal based fermented staple food. J. Cereal Sci. 2019, 87, 225-230. [CrossRef] 
85. Hor, P.K.; Ray, M.; Pal, S.; Ghosh, K.; Soren, J.P.; Maiti, S.; Bera, D.; Singh, S.; Dwivedi, S.; Takó, M.; et al. Some functional properties of khambir, an ethnic fermented cereal-based food of western himalayas. Front. Microbiol. 2019, 10, 1-13. [CrossRef]

86. Khusro, A.; Aarti, C.; Dusthackeer, A.; Agastian, P. Anti-tubercular and probiotic properties of coagulase-negative staphylococci isolated from Koozh, a traditional fermented food of South India. Microb. Pathog. 2018, 114, 239-250. [CrossRef]

87. Ezekiel, C.N.; Ayeni, K.I.; Ezeokoli, O.T.; Sulyok, M.; Van Wyk, D.A.B.; Oyedele, O.A.; Akinyemi, O.M.; Chibuzor-Onyema, I.E.; Adeleke, R.A.; Nwangburuka, C.C.; et al. High-throughput sequence analyses of bacterial communities and multi-mycotoxin profiling during processing of different formulations of Kunu, a traditional fermented beverage. Front. Microbiol. 2019, 10, 1-17. [CrossRef] [PubMed]

88. Chilton, S.N.; Burton, J.P.; Reid, G. Inclusion of Fermented Foods in Food Guides around the World. Nutrients 2015, 390-404. [CrossRef] [PubMed]

89. Jo, M.; Jung, J.H.; Kim, H.W.; Lee, S.J.; Chi, Y.M.; Jee, H.S.; Yoon, T.J.; Shin, K.-S. Polysaccharide isolated from fermented barley activates innate immune system and anti-tumor metastasis in mice. J. Cereal Sci. 2020, 92, 102919. [CrossRef]

90. Peñas, E.; Diana, M.; Frias, J.; Quílez, J.; Martínez-Villaluenga, C. A Multistrategic Approach in the Development of Sourdough Bread Targeted Towards Blood Pressure Reduction. Plant Foods Hum. Nutr. 2015, 70, 97-103. [CrossRef] [PubMed]

91. Gibson, G.R.; Hutkins, R.; Sanders, M.E.; Prescott, S.L.; Reimer, R.A.; Salminen, S.J.; Scott, K.; Stanton, C.; Swanson, K.S.; Cani, P.D.; et al. Expert consensus document: The International Scientific Association for Probiotics and Prebiotics (ISAPP) consensus statement on the definition and scope of prebiotics. Nat. Rev. Gastroenterol. Hepatol. 2017, 14, 491-502. [CrossRef] [PubMed]

92. Scott, K.P.; Grimaldi, R.; Cunningham, M.; Sarbini, S.R.; Wijeyesekera, A.; Tang, M.L.K.; Lee, J.C.-Y.; Yau, Y.F.; Ansell, J.; Theis, S.; et al. Developments in understanding and applying prebiotics in research and practice-An ISAPP conference paper. J. Appl. Microbiol. 2020, 128, 934-949. [CrossRef]

93. Tomasik, P.; Tomasik, P. Probiotics, Non-Dairy Prebiotics and Postbiotics in Nutrition. Appl. Sci. 2020, 10, 1470. [CrossRef]

94. Khangwal, I.; Shukla, P. Potential prebiotics and their transmission mechanisms: Recent approaches. J. Food Drug Anal. 2019, 27, 649-656. [CrossRef]

95. Tamura, K.; Hemsworth, G.R.; Déjean, G.; Rogers, T.E.; Pudlo, N.A.; Urs, K.; Jain, N.; Davies, G.J.; Martens, E.C.; Brumer, H. Molecular Mechanism by which Prominent Human Gut Bacteroidetes Utilize Mixed-Linkage Beta-Glucans, Major Health-Promoting Cereal Polysaccharides. Cell Rep. 2017, 21, 417-430. [CrossRef]

96. Wang, J.; Bai, J.; Fan, M.; Li, T.; Li, Y.; Qian, H.; Wang, L.; Zhang, H.; Qi, X.; Rao, Z. Cereal-derived arabinoxylans: Structural features and structure-activity correlations. Trends Food Sci. Technol. 2020, 96, 157-165. [CrossRef]

97. Delzenne, N.M.; Olivares, M.; Neyrinck, A.M.; Beaumont, M.; Kjølbæk, L.; Larsen, T.M.; Benítez-Páez, A.; Romaní-Pérez, M.; Garcia-Campayo, V.; Bosscher, D. Nutritional interest of dietary fiber and prebiotics in obesity: Lessons from the MyNewGut consortium. Clin. Nutr. 2020, 39, 414-424. [CrossRef] [PubMed]

98. Vitaglione, P.; Mennella, I.; Ferracane, R.; Rivellese, A.A.; Giacco, R.; Ercolini, D.; Gibbons, S.M.; La Storia, A.; Gilbert, J.A.; Jonnalagadda, S. Whole-grain wheat consumption reduces inflammation in a randomized controlled trial on overweight and obese subjects with unhealthy dietary and lifestyle behaviors: Role of polyphenols bound to cereal dietary fiber. Am. J. Clin. Nutr. 2015, 101, 251-261. [CrossRef] [PubMed]

99. Barczynska, R.; Kapusniak, J.; Litwin, M.; Slizewska, K.; Szalecki, M. Dextrins from maize starch as substances activating the growth of bacteroidetes and actinobacteria simultaneously inhibiting the growth of firmicutes, responsible for the occurrence of obesity. Plant Foods Hum. Nutr. 2016, 71, 190-196. [CrossRef] [PubMed]

100. Barczynska, R.; Jurgoński, A.; Slizewska, K.; Juśkiewicz, J.; Kapusniak, J. Corn starch dextrin changes intestinal microbiota and its metabolic activity in rats fed a basal and high-fat diet. Br. Food J. 2019, 121, 2219-2232. [CrossRef]

101. Lynch, K.M.; Coffey, A.; Arendt, E.K. Exopolysaccharide producing lactic acid bacteria: Their techno-functional role and potential application in gluten-free bread products. Food Res. Int. 2018, 110, 52-61. [CrossRef] 
102. Abedfar, A.; Hosseininezhad, M.; Rafe, A. Effect of microbial exopolysaccharide on wheat bran sourdough: Rheological, thermal and microstructural characteristics. Int. J. Biol. Macromol. 2020, 154, 371-379. [CrossRef]

103. Amaretti, A.; Bottari, B.; Morreale, F.; Savo Sardaro, M.L.; Angelino, D.; Raimondi, S.; Rossi, M.; Pellegrini, N. Potential prebiotic effect of a long-chain dextran produced by Weissella cibaria: An in vitro evaluation. Int. J. Food Sci. Nutr. 2020, 1-9. [CrossRef]

104. Wolter, A.; Hager, A.-S.; Zannini, E.; Galle, S.; Gänzle, M.G.; Waters, D.M.; Arendt, E.K. Evaluation of exopolysaccharide producing Weissella cibaria MG1 strain for the production of sourdough from various flours. Food Microbiol. 2014, 37, 44-50. [CrossRef]

105. Kajala, I.; Mäkelä, J.; Coda, R.; Shukla, S.; Shi, Q.; Maina, N.H.; Juvonen, R.; Ekholm, P.; Goyal, A.; Tenkanen, M.; et al. Rye bran as fermentation matrix boosts in situ dextran production by Weissella confusa compared to wheat bran. Appl. Microbiol. Biotechnol. 2016, 100, 3499-3510. [CrossRef]

106. Morreale, F.; Benavent-Gil, Y.; Rosell, C.M. Inulin enrichment of gluten free breads: Interaction between inulin and yeast. Food Chem. 2019, 278, 545-551. [CrossRef]

107. Moorthy, M.; Chaiyakunapruk, N.; Jacob, S.A.; Palanisamy, U.D. Prebiotic potential of polyphenols, its effect on gut microbiota and anthropometric/clinical markers: A systematic review of randomised controlled trials. Trends Food Sci. Technol. 2020, 99, 634-649. [CrossRef]

108. Espín, J.C.; González-Sarrías, A.; Tomás-Barberán, F.A. The gut microbiota: A key factor in the therapeutic effects of (poly) phenols. Biochem. Pharmacol. 2017, 139, 82-93. [CrossRef] [PubMed]

109. Dueñas, M.; Muñoz-González, I.; Cueva, C.; Jiménez-Girón, A.; Sánchez-Patán, F.; Santos-Buelga, C.; Moreno-Arribas, M.; Bartolomé, B. A survey of modulation of gut microbiota by dietary polyphenols. Biomed. Res. Int. 2015, 2015, 1-15. [CrossRef] [PubMed]

110. Kristek, A.; Wiese, M.; Heuer, P.; Kosik, O.; Schär, M.Y.; Soycan, G.; Alsharif, S.; Kuhnle, G.G.C.; Walton, G.; Spencer, J.P.E. Oat bran, but not its isolated bioactive $\beta$-glucans or polyphenols, have a bifidogenic effect in an in vitro fermentation model of the gut microbiota. Br. J. Nutr. 2019, 121, 549-559. [CrossRef] [PubMed]

111. Gupta, R.K.; Gangoliya, S.S.; Singh, N.K. Reduction of phytic acid and enhancement of bioavailable micronutrients in food grains. J. Food Sci. Technol. 2015, 52, 676-684. [CrossRef] [PubMed]

112. Samtiya, M.; Aluko, R.E.; Dhewa, T. Plant food anti-nutritional factors and their reduction strategies: An overview. Food Prod. Process. Nutr. 2020, 5, 1-14. [CrossRef]

113. Kiewlicz, J.; Rybicka, I. Minerals and their bioavailability in relation to dietary fiber, phytates and tannins from gluten and gluten-free flakes. Food Chem. 2020, 305, 125452. [CrossRef]

114. Hellström, A.M.; Vázques-Juárez, R.; Svanberg, U.; Andlid, T.A. Biodiversity and phytase capacity of yeasts isolated from Tanzanian togwa. Int. J. Food Microbiol. 2010, 136, 352-358. [CrossRef]

115. Kruger, J.; Taylor, J.R.N.; Oelofse, A. Effects of reducing phytate content in sorghum through genetic modification and fermentation on in vitro iron availability in whole grain porridges. Food Chem. 2012, 131, 220-224. [CrossRef]

116. Kumar, V.; Sinha, A.K. Chapter 3-General aspects of phytases. In Enzymes in Human and Animal Nutrition; Nunes, C.S., Kumar, V., Eds.; Academic Press: Cambridge, MA, USA, 2018; pp. 53-72. ISBN 978-0-12-805419-2.

117. Magala, M.; Kohajdová, Z.; Karovičová, J. Degradation of phytic acid during fermentation of cereal substrates. J. Cereal Sci. 2015, 61, 94-96. [CrossRef]

118. Yildirim, R.M.; Arici, M. Effect of the fermentation temperature on the degradation of phytic acid in whole-wheat sourdough bread. LWT 2019, 112, 108224. [CrossRef]

119. Castro-Alba, V.; Lazarte, C.E.; Perez-Rea, D.; Carlsson, N.-G.; Almgren, A.; Bergenståhl, B.; Granfeldt, Y. Fermentation of pseudocereals quinoa, canihua, and amaranth to improve mineral accessibility through degradation of phytate. J. Sci. Food Agric. 2019, 99, 5239-5248. [CrossRef] [PubMed]

120. Mohapatra, D.; Patel, A.S.; Kar, A.; Deshpande, S.S.; Tripathi, M.K. Effect of different processing conditions on proximate composition, anti-oxidants, anti-nutrients and amino acid profile of grain sorghum. Food Chem. 2019, 271, 129-135. [CrossRef] [PubMed]

121. Sathe, S.K.; Liu, C.; Zaffran, V.D. Food Allergy. Annu. Rev. Food Sci. Technol. 2016, 7, 191-220. [CrossRef] [PubMed]

122. Okolie, C.L.; Aryee, A.N.A.; Udenigwe, C.C. Detection and Deactivation of Allergens in Food, 2nd ed.; Elsevier Ltd.: Amsterdam, The Netherlands, 2018; ISBN 9780081007297. 
123. Stefańska, I.; Piasecka-Jóźwiak, K.; Kotyrba, D.; Kolenda, M.; Stecka, K.M. Selection of lactic acid bacteria strains for the hydrolysis of allergenic proteins of wheat flour. J. Sci. Food Agric. 2016, 96, 3897-3905. [CrossRef] [PubMed]

124. Kosová, K.; Leišová-Svobodová, L.; Dvořáček, V. Oats as a Safe Alternative to Triticeae Cereals for People Suffering from Celiac Disease? A Review. Plant Foods Hum. Nutr. 2020. [CrossRef]

125. Di Cagno, R.; De Angelis, M.; Auricchio, S.; Greco, L.; Clarke, C.; De Vincenzi, M.; Giovannini, C.; D’Archivio, M.; Landolfo, F.; Parrilli, G.; et al. Sourdough Bread Made from Wheat and Nontoxic Flours and Started with Selected Lactobacilli Is Tolerated in Celiac Sprue Patients. Appl. Environ. Microbiol. 2004, 70, 1088-1096. [CrossRef]

126. Di Cagno, R.; Barbato, M.; Di Camillo, C.; Rizzello, C.G.; De Angelis, M.; Giuliani, G.; De Vincenzi, M.; Gobbetti, M.; Cucchiara, S. Gluten-free Sourdough Wheat Baked Goods Appear Safe for Young Celiac Patients: A Pilot Study. J. Pediatr. Gastroenterol. Nutr. 2010, 51, 777-783. [CrossRef]

127. Rizzello, C.G.; De Angelis, M.; Coda, R.; Gobbetti, M. Use of selected sourdough lactic acid bacteria to hydrolyze wheat and rye proteins responsible for cereal allergy. Eur. Food Res. Technol. 2006, 223, 405-411. [CrossRef]

128. De Angelis, M.; Rizzello, C.G.; Fasano, A.; Clemente, M.G.; De Simone, C.; Silano, M.; De Vincenzi, M.; Losito, I.; Gobbetti, M. VSL\#3 probiotic preparation has the capacity to hydrolyze gliadin polypeptides responsible for Celiac Sprue probiotics and gluten intolerance. Biochim. Biophys. Acta Mol. Basis Dis. 2006, 1762, 80-93. [CrossRef]

129. Gänzle, M.G.; Loponen, J.; Gobbetti, M. Proteolysis in sourdough fermentations: Mechanisms and potential for improved bread quality. Trends Food Sci. Technol. 2008, 19, 513-521. [CrossRef]

130. Rahaman, T.; Vasiljevic, T.; Ramchandran, L. Effect of processing on conformational changes of food proteins related to allergenicity. Trends Food Sci. Technol. 2016, 49, 24-34. [CrossRef]

131. Stiemsma, L.T.; Nakamura, R.E.; Nguyen, J.G.; Michels, K.B. Does Consumption of Fermented Foods Modify the Human Gut Microbiota? J. Nutr. 2020. [CrossRef] [PubMed]

132. Niemi, P.; Pihlajaniemi, V.; Rinne, M.; Siika-aho, M. Production of sugars from grass silage after steam explosion or soaking in aqueous ammonia. Ind. Crop. Prod. 2017, 98, 93-99. [CrossRef]

133. Rinninella, E.; Raoul, P.; Cintoni, M.; Franceschi, F.; Miggiano, G.; Gasbarrini, A.; Mele, M. What is the Healthy Gut Microbiota Composition? A Changing Ecosystem across Age, Environment, Diet, and Diseases. Microorganisms 2019, 7, 14. [CrossRef] [PubMed]

134. Dimidi, E.; Cox, S.R.; Rossi, M.; Whelan, K. Fermented Foods: Definitions and Characteristics, Impact on the Gut Microbiota and Effects on Gastrointestinal Health and Disease. Nutrients 2019, 11, 1806. [CrossRef]

135. Kim, H.C.; Choi, W.J.; Ryu, J.H.; Maeng, S.K.; Kim, H.S.; Lee, B.C.; Song, K.G. Optimizing Cultivation Strategies for Robust Algal Growth and Consequent Removal of Inorganic Nutrients in Pretreated Livestock Effluent. Appl. Biochem. Biotechnol. 2014, 174, 1668-1682. [CrossRef] [PubMed]

136. David, L.A.; Maurice, C.F.; Carmody, R.N.; Gootenberg, D.B.; Button, J.E.; Wolfe, B.E.; Ling, A.V.; Devlin, A.S.; Varma, Y.; Fischbach, M.A. Diet rapidly and reproducibly alters the human gut microbiome. Nature 2014, 505, 559-563. [CrossRef]

137. Singh, R.K.; Chang, H.-W.; Yan, D.; Lee, K.M.; Ucmak, D.; Wong, K.; Abrouk, M.; Farahnik, B.; Nakamura, M.; Zhu, T.H. Influence of diet on the gut microbiome and implications for human health. J. Transl. Med. 2017, 15, 73. [CrossRef] [PubMed]

138. Sanz, Y. Effects of a gluten-free diet on gut microbiota and immune function in healthy adult humans. Gut Microbes 2010, 1, 135-137. [CrossRef] [PubMed]

139. Chan, M.; Baxter, H.; Jespersen, L.; Ekinci, E.I.; Howell, K. Impact of botanical fermented foods on metabolic biomarkers and gut microbiota in adults with metabolic syndrome and type 2 diabetes: A systematic review protocol. BMJ Open 2019, 9. [CrossRef]

(C) 2020 by the authors. Licensee MDPI, Basel, Switzerland. This article is an open access article distributed under the terms and conditions of the Creative Commons Attribution (CC BY) license (http://creativecommons.org/licenses/by/4.0/). 